\title{
Conflict and Cooperation in Long-Term Contracts
}

\author{
Robert E. Scott $\uparrow$
}

This Article uses the techniques of modern decision analysis and game theory to analyze the decisionmaking strategies of parties to long-term commercial contracts. Most parties to long-term contracts initially allocate the risks of future contingencies and agree-either explicitly or implicitly-to adjust this initial risk-allocation scheme if unanticipated events occur. Once contract risks are initially distributed, however, each party's self-interest may compel them to evade their responsibility rather than adjust cooperatively as originally agreed. Visualizing the interactions between contracting parties as an iterated prisoner's dilemma, the Author attempts to clarify the dynamics of this adjustment process. Professor Scott employs a game theoretic model to demonstrate that two polar behavioral patterns-either conflict or cooperation-would dominate if parties were unable to bargain over adjustment. However, this choice may not occur, he suggests, because even parties that are precluded from negotiating each adjustment option, nevertheless can communicate their intentions to each other. Under these conditions, a cooperative equilibrium will emerge so long as one of the parties commits to a strategy of conditional cooperation before the first adjustment is necessary. Professor Scott notes that in more realistic contractual situations, some breakdowns in patterns of mutual cooperation are inevitable. In actual contract settings, substantial problems of information and enforcement may threaten the parties' efforts to realize a cooperative equilibrium. Nevertheless, he concludes that parties in continuing relationships can invoke various legal and extralegal mechanisms to reduce these information and enforcement deficits and strengthen the existing matrix of social and contractual norms.

$\dagger$ Lewis F. Powell, Jr. Professor of Law, University of Virginia.

I would like to thank Ken Abraham, Frank Buckley, Robert Clark, Clay Gillette, Victor Goldberg, Tom Jackson, John Jeffries, Doug Leslie, Saul Levmore, Jon Macey, Alan Schwartz, Bill Stuntz, and the participants in faculty workshops at the Harvard Law School and McGill University for their helpful comments on earlier versions of this article.

Many of the ideas in this essay have been developed in the course of a decade-long collaboration with Charles Goetz. I am obliged, therefore, to share with Goetz the credit for any insights the Article contributes. The errors are all mine.

A version of this paper was presented at the International Symposium on The Complex LongTerm Contract, held on the occasion of the 600th anniversary of the University of Heidelberg, Heidelberg, Germany, October 2-4, 1986. 


\section{INTRODUCTION}

The law governing long-term contracts appears to be in disarray. Inconsistent application of the legal doctrines of commercial impracticability and frustration by courts betrays widespread judicial confusion over the proper conditions for excusing or adjustimg the obligations of parties to long-term contracts. ${ }^{1}$ Similar uncertainties frustrate attempts to prescribe regular ineanings for key contractual formulations such as good faith adjustment ${ }^{2}$ and force inajeure. ${ }^{3}$ This doctrinal confusion is symptomatic of a deeper conceptual uncertainty: What is the proper role of legal rules in the regulation of long-tern contractual relationships?

The tensions that underlie the legal regulation of long-tern contracts have been particularly evident in recent years. Many contractual breakdowns were triggered by the sudden inflation of energy prices during the past decade. The resulting litigation has revealed the apparent inadequacy of existing common law responses. Courts offer only two alternatives: Enforce fully the initial risk distribution scheme or excuse

1. Compare Iowa Elec. Light \& Power Co. v. Atlas Corp., 467 F. Supp. 129 (N.D. Iowa 1978) (equitable adjustment denied), rev'd on other grounds, 603 F.2d 1301 (8th Cir. 1979), cert. denied. 445 U.S. 911 (1980) and Missouri Pub. Serv. Co. v. Peabody Coal Co., 583 S.W.2d 721 (Mo. Ct. App.) (adjustment of outmoded price escalator index refused), cert. denied, 444 U.S. 865 (1979) with Aluminum Co. of Am. v. Essex Group, Inc., 499 F. Supp. 53 (W.D. Pa. 1980) (price adjustment mechanism reformed due to "mutual mistake").

The most curious aspect of the commercial impracticability cases decided over the past 20 years has been the courts' steadfast refusal to grant excuse for nonperformance despite the apparent invitation to do so in the Uniform Commercial Code and the Second Restatement. See U.C.C. § 2 615 and comment 1 (1983); Restatement (SECOND) of CoNTRACTS $\$ \$ 261-266$ (1981); cases cited in Stroh, The Failure of the Doctrine of Impracticability, 5 CoRP. L. REv. 195, 207-16 (1982). For a discussion of the relationship between judicial attitudes and the complexity of the issues in excuse cases, see A. SchwarTZ \& R. ScotT, Commercial TRANSACtions 415-18, 427-28, 449-57 (1982); see also Schwartz, Sales Law and Inflations, 50 S. CaL. L. REv. 1, 2-20 (1976) (discussing issues such as foreseeability, harshness of seller's burden, windfall gains, and causation).

2. Good faith adjustment clauses (also known as "renegotiation" or "gross inequities" clauses) are contractual provisions that require a common effort of the parties to agree, for various reasons, to a substantial, material change of the contractual allocation of risks. These clauses authorize changes in a contract without following any automatic or predetermined pattern. See W. Peter, ARbitration and Renegotiation of International INVESTMENT AgreEMENTS 153-55 (1986). A typical example includes the following language: "In case of profound change in the circumstances ...., the parties, at the request of any one of them, will consult together for the purpose of considering such changes in this ... [a]greement as the parties deem to be appropriate." Id. at 155 (quoting a 1974 supplemental agreement to a 1960 "LAMCO" Iron-Orc Agreement). Despite the frequent use of adjustment clauses in long-term contracts, it remains unclear whether, and to what extent, they are legally enforceable. See infra text accompanying notes 147 \& 148 .

3. "Force majeure" has been held to include: "all circumstances independent of the will of man, and which it is not in his power to control, and such force majeure is suffieient to justify the non-execution of a contract. Thus, war, inundations, and epidemics are cases of force majeure; [as is] a strike of workmen." Lebeaupin v. Richard Crispin \& Co., [1920] 2 K.B. 714, 719 (quoting L. Goirand, A Treatise upon French Commercial LaW 854 (2d ed. 1898). Standard force majeure provisions deal adequately with these routine situations but appear unable to allocate the risks of "economic" contingencies, such as an oil embargo or an unstable labor force. See infra text accompanying notes $144-46$. 
the adversely affected performance entirely. ${ }^{4}$ An increasingly lively academic debate has centered on the single normative question of when, if ever, courts should intervene to equitably adjust the risks of long-term contracting. ${ }^{5}$

There are several reasons why this key question reinains unresolved. In the first place, we lack a workable theory of contractual behavior to illuminate the decisionmaking strategies parties use to accommodate the stresses and tensions that threaten their relationship. Parties enter into continuing contractual relationships in order to exploit the economic benefits of long-term planning and coordination. Even so, contingencies may later inaterialize and frustrate the parties' efforts to realize these shared objectives. Anticipating this, contracting parties inust distribute between themselves the risks of their enterprise.

Althougli there are a wide variety of risk-bearing options, all coinniercial contractors have two dommant inotivations. Initially, the parties wish to distribute risks in the least burdensome way. Thereafter, parties seek to adjust initial risk assignments in light of subsequent events so as to realize greater benefits fron their joint enterprise. These risk distribution and adjustınent objectives are highly interactive and frequently in conflict. The resulting tension is thus an inevitable consequence of the fundamental incoinpatibility between the desire to reduce the collective burden of risk bearmg and tlie desire to adjust individual responsibilities over tinie.

Developing a inodel of contractual behavior is further coinplicated by the interactions between the legal and social norms that regulate continuing contractual relationships. ${ }^{6}$ This Article aims only at a beginning.

4. But see Coons, Approaches to Court Imposed Compromise-The Uses of Doubt and Reason, 58 Nw. U.L. Rev. 750 (1964); Coons, Compromise as Precise Justice, 68 CalIF. L. REv. 250 (1980); Daube, The Scales of Justice, 63 JURID. REV. 109 (1951).

5. The legal scholarship on long-term contracting has tended to focus on either the risk distribution objective or the adjustment objective, but not both. Thus, many of the insights of the recent scholarship are flawed by analyses that are insufficiently coinprehensive. For a review of the issues and of the best commentary in the academic debate, see Gillette, Commercial Rationality and the Duty to Adjust Long-Term Contracts, 69 MinN. L. Rev. 521 (1985); Goldberg, Price Adjustments in Long-Term Contracts, 1985 WIS. L. Rev. 527; Harrison, A Case for Loss Sharing, 56 S. CAL. L. REv. 573 (1983); Hillman, Court Adjustment of Long-Term Contracts: An Analysis Under Modern Contract Law, 1987 Duke L.J. 1; Macaulay, Non-Contractual Relations in Business: A Preliminary Study, 28 AM. Sociological REv. 55 (1963); Macneil, Contracts: Adjustment of Long-Term Economic Relations Under Classical, Neo-Classical and Relational Contract Law, 72 Nw. U.L. REv. 854 (1978); Posner \& Rosenfield, Impossibility and Related Doctrines in Contract Law: An Economic Analysis, 6 J. LEgAL STUD. 83 (1977); Speidel, Court-Imposed Price Adjustments Under Long-Term Supply Contracts, 76 Nw. U.L. REv. 369 (1981) [hereinafter Speidel, Court-Imposed Price Adjustments]; Speidel, Excusable Nonperformance in Sales Contracts: Some Thoughts about Risk Management, 32 S.C.L. REV. 241 (1980) [hereinafter Speidel, Excusable Nonperformance]; Trakman, Winner Take Some: Loss Sharing and Commercial Impracticability, 69 MINN. L. REV. 471 (1985).

6. See I. Macneil, The New Social Contract: AN InQuiry into Modern 
My purpose is to advance the normative debate by using the techniques of modern decision analysis and game theory; first to clarify the relationship between the risk distribution and adjustment functions of contract; and then to suggest how legal rules can function to ameliorate tensions in efforts to reallocate risks.

In Part I of the Article, I develop a conceptual framework for analyzing the decisionmaking strategies of parties to long-term commercial contracts. Because no strategy can efficiently distribute the risk of all contingencies at the time of contracting, parties agree-either explicitly or implicitly-to adjust their initial risk allocation scheine in order to accommodate subsequent events. Unhappily, once contract risks are initially distributed, each party has less incentive to accoininodate the other's subsequent request for adjustinent. Each party thus confronts, repeatedly, a difficult choice: whether to adjust cooperatively (as originally agreed) or to respond to inmediate self-interest and evade the responsibility.

Obviously, if parties can costlessly renegotiate the distribution of risks, a cooperative adjustment will be achieved. ${ }^{7}$ But how do parties respond to the adjustment choice when they are effectively precluded froin bargaining? By visualizing the interactions between contracting parties as a strategic interaction game, we can better understand how nonbargained reciprocal patterns regulate contractual behavior. A gaine theory model suggests that two opposing and polar behavioral patterns would einerge if parties were unable to bargain over adjustınent. Many parties, motivated by the prospect of future interactions, would develop patterns of cooperative adjustment despite their inability to renegotiate the risk assiguments. Unfortunately, the same forces that proinote stable patterns of cooperation would also reinforce a counterpattern of exploitation and conflict. ${ }^{8}$ To resolve this indeterminacy, I then add the more realistic assumption that the parties, although precluded from negotiating each adjustınent option, are nevertheless able to communicate their intentions to each other. Under these conditions, I conclude, a cooperative equilibrium will result eventually whenever one of the parties

Contractual Relations (1980); Macneil, Values in Contract: Internal and External, 78 Nw. U.L. REv. 340 (1983); Macneil, The Many Futures of Contracts, 47 S. CAL. L. Rev. 691 (1974).

7. See generally R. AXELrod, The EVolution of CoOperation 88, 104 (1984) (discussing the evolution of cooperative patterns and their resistance to noncooperative behaviors); see also infra note 54 and accompanying text.

8. This does not imply that the renegotiated agreement will be socially optimal. The terms of the renegotiation, as well as the parties' incentives to take precautions to prevent breakdowns, will depend on a number of other variables including the legal remedies for breach of contract. See Craswell, Contract Remedies, Renegotiation, and the Theory of Efficient Breach, (forthcoming, $61 \mathrm{~S}$. CAL. L. Rev. (1988). 
"precommits" to a strategy of conditional cooperation prior to the first adjustment.

In Part II, I relax the assumptions of the model in order to examme the dynamics of risk allocation and adjustment in more realistic contractual environments. Under these conditions, substantial problems of information and enforcement appear to upset efforts to realize a cooperative equilibrium. However, parties in contmuing relationships are able to invoke use and contractual mechanisms to reduce these information and enforcement deficits. In addition, recourse to legal mechanisms seems to strengthen the existimg matrix of social and contractual norms. The parties can assign the various risks of the enterprise more clearly because they can use standardized terms that have been blessed with legal meanings. Moreover, the ongoing process of adjustment is enhanced by having legal means to deter large-scale defections from the cooperative norm. Unfortunately, however, recourse to the legal system generates offsetting costs. The limits of legal and extralegal regulation thus suggest that occasional breakdowns in emerging patterns of mutual cooperation are inevitable.

The highly interactive nature of the parties' response to problems of noucooperation makes the effects of any legally imposed adjustment largely unpredictable. Adjusting losses coercively may sometimes be consistent with the cooperative strategies the parties have developed. But, equally likely, courts may fail to perceive that a particular noncooperative response is necessary im order to preserve the general cooperative equilibrium. I conclude, therefore, that the existing foundation of highly complex social and contractual norms requires broad party autonomy in selecting, ex ante, the best complement of legal devices to mitigate information and enforcement deficiencies. These custormzed mechanisms, together with the "discipline of contmuous dealings," will generate stable patterns of mutual cooperation in most contracts.

\section{A Cooperative Game Theory of Contractual BEHAVIOR}

\section{A. Limits of the Bargain Model}

The bargain theory of contract has dominated American jurispru-

9. A. Smith, The Wealth of Nations 700 (E. Cannon ed. 1937) (1776). Ian Macneil has written: "[My] students all ... know that I invented relational contract, and I daresay Stewart Macaulay's students all know that he invented relational contract." Macneil, Relational Contract: What We Do and Do Not Know, 1985 Wis. L. Rev. 483, 483. Amazingly, my students all know that Goetz and I invented relational contract. See, e.g., Goetz \& Scott, Principles of Relational Contracts, 67 VA. L. REV. 1089 (1981). But as the quotation in the text reveals, each of us was anticipated, as in all things, by another Scot, Adam Smith. 
dence for well over one hundred years. The modern conceptualization of that paradigm extends to hypothetical bargains as well. This approach evaluates legal rules by asking what set of arrangements the affected parties would have adopted had they bargained over such issues in advance. Whether in classical or contemporary form, the remarkable durability of the bargain theory rests on a single idea: contracting parties can (and do) agree explicitly on how the risks of their enterprise should be distributed.

But many private contracts do not easily fit the presuppositions of the classical bargain analysis. In relational contexts, where the future contingencies are complex and uncertain, the bargain theory generates two forms of bias. First, bargain theory ignores the barriers to executory contracting, or ex ante bargaining, that characterize many contractual settings. There is inounting social science evidence that individuals inake systematic errors in their cognitive judgments and decisions: errors that inpair their ability to achieve fully a desired objective through executory bargains. ${ }^{10}$ Second, bargain theory ignores the significant barriers to renegotiation, or ex post bargaining, that exist in many contractual relationships. Despite the physical proximity of the parties or their technological capacity to interact, strategic considerations frequently block the disclosure of information necessary to any renegotiation. Because, these bargaining impediments influence the structure of the ongoing contractual relationship, they need to be explicitly included in any model of contractual behavior.

Parties generally enter into long-term contracts only after considering alternative methods of achieving their objectives. One obvious alternative is vertically integrating several activities into a single firm. Parties may choose vertical integration if the benefits of central manageinent exceed the cost of momitoring within the firm. In many commercial settings, however, vertical integration is not a feasible option. ${ }^{11}$

Another alternative is sequential, rather than long-term, contracting. By negotiating a series of recurring short-term contingent contracts, the parties can often reduce the barriers to bargaining that might otherwise impair the relationship. ${ }^{12}$ Unfortunately, the performance of

10. See Scott, Error and Rationality in Individual Decision-Making: An Essay on the Relationship Between Cognitive Illusions and the Management of Choices, 59 S. CAL. L. REV. 329, 332-47 (1986).

11. A number of factors may make vertical integration less attractive than alternativc contractual forms. These factors are not all related to production efficiencies and transaction costs. For instance, vertical integration may trigger costly forms of governmental regulation including workers' compensation, social security, and labor law regulations. See Goldberg, The Law and Economics of Vertical Restrictions: A Relational Perspective, 58 TEx. L. REv. 91, 120 (1979).

12. By arbitrarily constraining the duration of the contract, the parties can reduce both the uncertainty regarding the magnitude of future contingencies and the complexity of assigning these risks. So long as the performance of such short-term contracts does not create contract-specific investments, the problem of strategic bargaining will not arise upon renegotiation because each party 
the initial agreement will often require specialized, contract-specific investments by both parties. As investments mount, each party becomes vulnerable to strategic demands by the other when the contract is periodically renegotiated. The threat of strategic or opportunistic behavior will, in turn, reduce each party's incentive to exploit fully the benefits of long-term planning and coordmation. In many circumstances, therefore, the combination of the parties' desire to secure the benefits of long-term planning and investment, and their mability otherwise to reduce the vulnerability that such investment necessarily creates, will imduce the parties to restrict themselves mutually by a long-term contract.

Imagine that two commercial parties have elected to enter into a long-term contract because they consider this arrangement more attractive than the available alternatives. Once this fundamental choice is made, the parties must consider the more vexing question of how to reduce the tensions inherent in long-term relationships. These tensions are an imevitable consequence of the incompatibility between the objectives of ex ante risk distribution and ex post adjustment.

Alcoa v. Essex ${ }^{13}$ offers a useful illustration of the challenges our two parties will confront. The contract between Alcoa and Essex required Alcoa to convert Essex's alumina into molten aluminum for a twentyyear period. In turn, Essex agreed to purchase up to forty million pounds of alumina per year from Alcoa. The initial contract price was fifteen cents per pound. This consisted of a fixed "demand" charge and a "production" charge that imcluded an adjustable component for nonlabor and labor costs. The non-labor costs were indexed to the wholesale price index and the labor costs to Alcoa's average hourly labor costs. The parties agreed to a ceiling price of $65 \%$ percent of the posted price of a specified type of aluminum.

The contractual relationship between Alcoa and Essex was severely strained when production costs rose dramatically in response to drastic increases in fuel prices in 1973. Adjustments in the contract price of aluminum did not keep pace with the rapidly increasing cost of producing it. The major cause of the discrepancy was the rise in nonlabor production costs that rose more than twice as rapidly as the wholesale price index. ${ }^{14}$ By 1979, Essex was receiving aluminum from Alcoa at 36 cents per pound and reselling it on the open market at 73 cents per pound.

Alcoa repeatedly attempted to renegotiate the contract with Essex. But all efforts to secure a voluntary adjustment failed. Ultimately, Alcoa

can use the market to monitor the value of its performance. See Goetz \& Scott, supra note 9, at 1100-02.

13. Aluminum Co. of Am. v. Essex Group, Inc., 499 F. Supp. 53 (W.D. Pa. 1980).

14. See Goldberg, supra note 5 , at 534-40 (synthesis of facts derived from the published decision and the briefs). 
refused to produce under the contract and the dispute went to trial. The trial court ruled that the nonlabor production index was a "mutual mistake" because it operated so badly. Rescission, however, would result in a windfall for Alcoa and deprive Essex of the benefits of its long-term contract. Accordingly, the court instead reformed the contract, rewriting the price term to insure Alcoa at least one cent per pound "profit."15

Clearly, the parties to the Alcoa-Essex contract encountered unanticipated problems, despite having received sophisticated legal and economic advice. ${ }^{16}$ Relational theory suggests two possible reasons why the relationship between the parties broke down. First, the inability of the parties to specify an effective price adjustment inechanism may reflect heretofore unrecognized obstacles that prevent parties froun successfully allocating risks at the time of contracting. Second, the parties' inability to inodify the contract in light of subsequent events suggests that additional barriers to renegotiation may also have contributed to the failure of the relationship.

The existing framework of legal regulations is generally considered insufficient for addressing these problems. ${ }^{17}$ Thus, in the aftermath of Alcoa, academic commentary has focused on the desirability of courtmiposed adjustments in long-term contracts. ${ }^{18}$ Unfortunately, this commentary fails to appreciate all of the forces that shape long-term contractual relationships. Before prematurely embracing court-imposed solutions the legal community must first comprehend the decisionmaking strategies parties such as Alcoa and Essex pursue in trying to overcome the impediments to maintaining long-term relationships.

\section{B. Barriers to Ex Ante Bargaining: The Limits of Risk Allocation Under Uncertainty}

\section{Strategies for Distributing Risk}

The dynainics of relational contracting are rich and multifaceted. Clarifying this coniplex process necessarily requires some abstraction in order to isolate the variables that most influence contracting behavior. To this end, I will assume initially that the probabilities and magnitudes of all exogenous contingencies (such as the risk of flood or earthquake) will remam constant through the duration of the contract. ${ }^{19}$ Thus, the

15. Id. at 535.

16. See id. at $537-40$.

17. See, e.g., Dawson, Judicial Revision of Frustrated Contracts: The United States, 64 B.U.L. REV. 1 (1984); Gillette, supra note 5, at 522; Goldberg, supra note 5, at 528; Harrison, supra note 5, at 581; Speidel, Excusable Nonperformance, supra note 5, at 241; Stroh, supra note 1, at 210; Trakman, supra note 5, at 471 .

18. See, e.g., Goldberg, supra note 5, at 537-40; Hillman, supra note 5 at 4-17; Speidel, CourtImposed Price Adjustments, supra note 5, at 377-80.

19. In other words, I assume that the parties attempt an initial risk-allocation strategy based 
parties' chief concern is how to allocate endogenous risks; for example, decisions about planting crops, building structures, or storing inventory. Even with this limiting assumption, it is not obvious how the parties will initially allocate such contract risks between them. Many of the contingencies that affect supply and demand conditions over the life of a longterin contract are too complex and uncertain for the parties to predict their likelihood or scope. Nevertheless, for certain contingencies a probability distribution over the possible "states of nature" is known-or the parties decide to act as if it were known. A logical place to begin, therefore, is to ask how contracting parties such as Alcoa and Essex might distribute the risk of such "foreseeable" contingencies.

Imagine that at the time they contracted both Alcoa and Essex know that certain "natural" variations in the quality of aluminum can be reduced, but only if special precautions are taken by Alcoa at the imitial stage of processing. Assume further that both parties are risk neutral; they care about the expected value of a loss but not its distribution. The parties thus confront a situation in which one party or the other can act in a way that alters the objective amount of risk in the world. When such actions are cost-beneficial, there is a potential gain to both parties if they can assign the entire risk of quality variations to the party best able to influence the amount of the risk. ${ }^{20}$

Using this strategy of risk control, the parties would allocate the entire risk of variations in the quality of aluminum to Alcoa. The advantage of this simple risk- assignment technique derives from Alcoa's ability to control the production process and other details of its own perforinance. As the party in control of the contracted performance, Alcoa is better able to undertake cost-effective precautions that will reduce the probability of quality variations. ${ }^{21}$

It is tempting to argne that contracting parties such as Alcoa and Essex might profit from a more sophisticated risk reduction strategy. ${ }^{22}$ For instance, in seeking the superior risk bearer, the parties might consider a variety of additional variables, such as relative access to inforination concerning the likely impact of any risk or ability to obtain thirdparty insurance against the risk. Ultimately, however, the benefits of risk control can be realized fully only by allocating foreseeable risks to the

on the premise that subsequent events will not alter their current assessment of the various risks and their probabilities. This assumption is explicitly relaxed later in the discussion.

20. C. Goetz, CASEs AND Materials on LAw AND Economics 127 (1984).

21. For an elaboration of this argument, see Goetz \& Scott, Liquidated Damages, Penalties and the Just Compensation Principle, 77 Colum. L. Rev. 554, 578-83 (1977).

22. See, e.g., Posner \& Rosenfield, supra note 5, at 90-92 (arguing for the relevance of insurance and other transaction costs in allocating the risk of nonperformance). But see Bruce, An Economic Analysis of the Impossibility Doctrine, 11 J. LEGAL STUD. 311, 320-23 (1982) (criticizing Posner \& Rosenfield). 
party whose performance is thereby affected. To see why this is so, assume that the parties assign the risk of quality variations to Essex based upon their calculation that Essex has better information concerning the impact of changes in product quality or can more readily secure third-party insurance. This arrangement will necessarily motivate Alcoa to undermvest in precautions to minimize the variance in product quality. Even if Essex were to atteinpt to exploit its advantage as the cheaper insurer, insurance costs necessarily would be greater because Essex lacks control over Alcoa's precautionary investinents. ${ }^{23}$

This conclusion may be generalized to all cases in which a party has soine control over the probability of externally caused nonperformance. If the risk bearer beheves that it possesses inadequate information to calculate the appropriate precautions, it need only request this information froin the other party. Any failure to provide the requested information would be grounds for avoiding the risk assignment. Indeed, damage limitation rules such as Hadley v. Baxendale ${ }^{24}$ encourage such an information exchange; enabling the risk bearer to calculate the likely impact of any foreseeable contingencies. ${ }^{25}$

In addition to the parties' control over risk, their subjective preferences for risk may also dictate allocation. This is the strategy of risk transfer: reducing risks merely by reallocating the consequences of a risk. Assuine, for exainple, that there is a difference in the risk preferences of Alcoa and Essex; they attach different subjective values to what is objectively the same risk. If the risk is not already allocated to the party who places the lowest monetary cost on it, then a transfer to that party, together with a compensatory payment to the risk bearer, will be mutually advantageous. Risk transfer thus reduces risk costs when an otherwise unchanged risk is allocated to a person who, if only for psychological reasons, attaches a lower money value to the risk. ${ }^{26}$

It is important to recognize that reduction in the subjective cost of risk through risk transfer is a very real reduction in cost. Nevertheless, several factors suggest that such transfers will not consistently be available as a risk distribution strategy. In the first place, the transaction costs of effecting the transfer inay dinninish or even overcoine the potential gain. Furthermore, the mere fact that the two parties have different utility functions does not guarantee a difference in risk preference. It is

23. See Goetz \& Scott, supra note 21 , at $578-83$.

24. 156 Eng. Rep. 145 (Ex. 1854); see generally Goetz \& Scott, The Mitigation Principle: Toward a General Theory of Contractual Obligation, 69 VA. L. REv. 967, 1012-15 (1983) (proposing that Hadley v. Baxendale be extended "to all those particular needs of which an obligee is unaware, if the obligor has reason to know of them at any time before performance is tendered." Id. at 1014).

25. See Goetz \& Scott, Enforcing Promises: An Examination of the Basis of Contract, 89 Y ALE L.J. 1261, 1298-1300 (1980).

26. See C. GoETZ, supra note 20, at 123-27. 
the relative difference in the intensity of feeling gains and losses that produces risk preference. ${ }^{27}$

Risk control and risk transfer are complementary, binary strategies; they reduce risks by allocating the entire risk to one party or the other. The initial allocation question becomes considerably more complex, however, when the parties also consider alternative, noncomplementary strategies. One such strategy is risk sharing. Risk sharing occurs when each party accepts a portion of an unchanged set of risks. If the contingencies are uncertain and both parties are risk averse, a risk-sharing scheme will reduce the amount of uncertainty and thus reduce the cost of the risk for each party ${ }^{28}$ Risk-averse parties benefit from a risk-sharing arrangeinent because it reduces the variance in risk; each has a higher probability of incurring a smaller future loss.

A common method of risk sharing is a price-adjustment mechanism such as that in the Alcoa-Essex contract. Price-adjustment arrangements reduce the variance between potential gains and losses and thus advance risk-sharing goals. Similarly, a liquidated damage clause, in which damages for particular contingencies are specified in advance, serves a risksharing as well as a risk-control purpose. ${ }^{29}$

\section{Making Risk-Distribution Choices Under Uncertainty}

In selecting a risk-bearing strategy, the parties must balance the expected gains from risk reduction against several categories of costs. Of particular relevance are the costs of negotiating the initial distribution schenie and the costs of subsequently monitoring and enforcing the assigninents as contingencies occur. ${ }^{30}$

While calculations cannot be precise, each of these cost considerations tend to support binary strategies-those that allocate entire risks to one party or the other-over risk-sharing alternatives. Negotiating a risk-sharing contract requires complex bargaining to reach agreenient on vexing distributional questions. On the other hand, binary risk-allocation strategies are easier to adopt because they depend on discernable

27. Id.

28. See Polinsky, Risk Sharing Through Breach of Contract Remedies, 12 J. Legal STUD. 427, 429-33 (1983).

29. Id. at 436.

30. On the relationship between risk-bearing choices and various categories of transaction costs, see Cheung, Transaction Costs, Risk Aversion, and the Choice of Contractual Arrangements, 12 J. L. \& ECoN. 23, 36-41 (1969) (transaction costs of short-term leases); Umbeck, $A$ Theory of Contract Choice and the California Gold Rush, 20 J. L. \& EcoN. 421, 422-28 (1977) (transaction costs in mining contracts). The tension between risk-allocation choices and the subsequent costs of maintaining the parties' incentives to perform is discussed in the economics literature. See, e.g., Shavell, The Design of Contracts and Remedies for Breach, 99 Q.J. EcoN. 121, $146-47$ (1984) (benefits of specific performance weighed against parties' risk-bearing abilities in relation to the type of contract). 
cognitive heuristics such as the criterion of risk-control. ${ }^{31}$ Although subject to bias, these heuristics are entrenched in individual behavior precisely because they simplify decisionmaking. ${ }^{32}$ For instance, historic facts provide a simple inechanism for applying a strategy of risk control. ${ }^{33}$ If historic facts reveal that the seller calmot efficiently reduce the probabilities of exogenous events such as labor strikes and embargoes, the parties can use a force inajeure clause to assign those risks to the buyer. ${ }^{34}$

Moreover, the cost of measuring and dividing the contractual product will be higher under a risk-sharing scheme. In general, the problems of measurement and division of responsibility increase witl the complexity of the contract. ${ }^{35}$ Because risk-sharing arrangements are inevitably more complex than bimary allocations, evasions of contractual responsibilities are more difficult to detect and to police. ${ }^{36}$ As a result, the cost of

31. For a review of the literature and a discussion of the relevance of cognitive heuristics to legal theory, see Scott, supra note 10; see also JUDGMENT UNDER UNCERTAINTY: HEURISTICS AND BiAsEs (D. Kahneman, P. Slovic \& A. Tversky eds. 1982) [hereinafter JudGMENT UNDER UNCERTAINTY]; D. VON WINTERFELDT \& W. EDWARDS, DECISION ANALYSIS AND BEHAVIORAI Research 533-47 (1986); Abelson \& Levi, Decision Making and Decision Theory, in 1 THe HANDBooK of Social Psychology 231 (G. Lindzey \& E. Aronson 3d ed. 1985).

32. Scott, supra note 10 , at 361-62.

33. For an argument that contracting parties derive their probability assessments principally through analysis of historic facts, see Narasimhan, Of Expectations, Incomplete Contracting, and the Bargain Principle, 74 CALIF. L. Rev. 1123, 1142-49 (1986). The use of historic facts is illustrative of the "representativeness" and "availability" heuristics. Individuals using the "representativeness" heuristic make probability assessments based on the assumption that the probability that object $A$ belongs to class $B$ is determined by the degree to which $A$ resembles $B$. See JUDGMENT UNDER UNCERTAINTY, supra note 31, at 32-33. The "availability" heuristic is a strategy for assessing probability based upon how readily prior instances or occurrences can be brought to mind. See id. at 190-92; Scott, supra note 10, at 335.

34. A force majeure provision exempts the performing party from responsibility for those exogenous risks he cannot control. See generally A. SCHWARTZ \& R. SCOTT, supra note 1, at 439.56 (1982) (cases and commentary on the role of exculpatory clauses in assigning risk).

A standard force majeure clause includes the following:

The term "force majeure" shall be deemed to include acts of God, fire, acts of civil or military authorities, acts of war, riots, insurrection, orders of court or regulatory agencies, strikes, lockouts or other industrial disturbances, breakage of or accidents to machinery, and any other cause, whether of the kind enumerated or otherwise, not within the control of the party claiming suspension of its obligations, and which by the exercise of due diligence such party is unable to avoid. It is understood and agreed that the settlement of strikes and labor disputes shall be entirely within the discretion of the party affected thereby.

Young, Construction and Enforcement of Long-Term Coal Supply Agreements-Coping With Conditions Arising From Foreseeable and Unforeseeable Events-Force Majeure and Gross Inequities Clauses, 27 Rocky MTN. Min. L. INst. 127, 140 (1980); see also Miss. CoDE ANN. § 75-2-617 (1972). See generally Kirkham, Force Majeure-Does It Really Work, 30 RockY MTN. MIN. L. INST. 6-1 (1984) (discussing the meaning and utility of force majeure clauses).

35. See Umbeck, supra note 30 , at $422-28$.

36. Cf. Erlich \& Posner, An Economic Analysis of Legal Rulemaking. 3 J. LegAL STUD. 257 (1974) (applying a similar analysis to tort law; addressing the difficulty of monitoring in eomplex arrangements). 
enforcement is higher with risk-sharing agreements than where the parties distribute risks through "all or nothing" rules.

Although a binary strategy is generally cheaper than risk sharing, its benefits decline sharply where risks depend on interactive or interdependent contingencies. ${ }^{37}$ To be sure, contracting parties can soinetimes make a binary assignment even without understanding the relationship among particular contingencies. Consider, for example, how the hypothetical contracting parties might assign the risk of increases in nonlabor production costs. The parties may not be able to estimate the imdependent effects of any particular contingency (for example, the extent to which disturbances among energy-producing nations might increase energy costs). Nevertheless, they still may be able to aggregate all the contingencies that affect nonlabor inputs by assigning the entire risk of such cost increases to the seller; the party who controls the production process.

In inany instances, however, the comparative advantage in risk bearing is divided between the parties. Thus, for example, the risk of increases in production costs may depend on several interactive variables such as the inverse relationship between energy costs and the demand for various factors of production. The seller may have a superior abihty to bear the risk of the first contingency, but the buyer may be better able to plan for the second. A risk-control strategy will not work because, regardless of how the parties define the "risk," neither party will enjoy an advantage in estimating both its probability and its likely impact. If the parties are unable to separate the contingencies, neither party can take cost-effective precautions independently. ${ }^{38}$

The limits of binary strategies in reducing the risk of interactive con-

37. See R. Luce \& H. RaIfFA, Games and Decisions 275-78 (1957). The term "contingency" is used here to refer to an event that might trigger a risk.

38. Contracting parties can attempt to solve this dilemma by selecting among well-known criteria for making decisions under conditions of ignorance. See generally R. LuCE \& H. RAIFFA, supra note 37, at 275-309 (discussing decision problems under uncertainty and evaluating various criteria for making choices); Arrow, Alternative Approaches to the Theory of Choice in Risk-Taking Situations, 19 ECONOMETRICA 404 (1951) (a survey of theories of choice in the face of uncertain consequences).

However, these criteria are often impractical to implement and can lead to undesirable results. For example, the "maximin" criteria (minimizing the maximum risk of loss) are extremely pessimistic-they require parties to ignore potential advantages of optimistic choices. See R. LUCE \& H. RAIFFA, supra note 37, at 278-83; Chernoff, Rational Selection of Decision Functions, 22 ECONOMETRICA 422, 424-26 (1954). More balanced approaches take account of optimistic choices by assigning a probability distribution to possible outcomes. However, these approaches require that the parties specify a mutually exclusive and exhaustive list of possible outcomes. Depending on the criterion used and differences in the lists of plausible future contingencies, different or intuitively unreasonable solutions may result. See R. LuCE \& H. RAIFFA, supra note 37, at 282-86; D. VoN WINTERFELDT \& W. EDWARDS, supra note 31, at 109-10. The difficulties with all these decision criteria are further magnified when the choice must be made in a bargaining context. 
tingencies suggest that the contracting parties will consider other means to reduce the burdens of risk bearing. If the parties are risk averse, they can alter the precontract distribution of possible outcomes through risk sharing. Risk sharing reduces the uncertainty associated with interactive contingencies. This, in turn, reduces each party's subjective cost of risk bearing. ${ }^{39}$ By hedging against the consequences of an uncertain world, both parties can raise their security levels and thereby reduce risk-bearing costs.

\section{Implications of the Distribution Dilemma}

Two tentative implications for ex ante bargaining follow from this analysis of risk allocation under uncertainty. First, we might predict that parties to long-term contracts would employ a mixed strategy for distributing risk. Binary allocations should be preferred whenever the contingencies are severable and the risks can be assessed individually. Risksharing arrangements should be preferred where the contingencies are too interactive to make such individual precautions meaningful. ${ }^{40}$

Casual observation confirms this initial prediction. In Alcoa, for example, many of the risks of contracting were borne entirely by one party or the other. The risk of quality variations, inadequate production capacity, and inventory shortages were all borne by the seller. Parallel risks affecting the demand for aluminum were borne by the buyer. Conversely, the uncertain effects of exogenous variables on endogenous production costs stimulate the search for a more complex pricing mechanism. The design of adjustable charges for nonlabor and labor inputs allowed the parties to share the risk of certain supply and demand contingencies.

The hypothesis that parties will pursue mixed strategies for distributing risk may also explain why courts have encountered such difficulty in applying the exculpatory doctrines of commercial frustration and impracticability. Courts have relied on the ex ante foreseeability of the contingency in determining whether to excuse an obligor from a burdensome performance. ${ }^{41}$ Foreseeability, however, is irrelevant to the choice

39. For discussions of the impact of risk aversion on contract choice, see Kornhauser, $A n$ Introduction to the Economic Analysis of Contract Remedies, 57 U. CoLo. L. REv. 683, 705-07 (1986).

40. There are, of course, some circumstances in which a "mixed" strategy for distributing risks will not be necessary. Some parties, perhaps such as Alcoa and Essex, can diversify internally, by entering into many long-term contracts with different partners. Under these conditions, they would not require a sharing rule in order to diversify risks. Such internal risk diversification could also occur by using a combination of short-term and long-term contracts.

41. Using the foreseeability test, the courts, with virtual unanimity, have rejected sellers' claims for relief from a performance that became more costly owing to an intervening contingency. See, e.g., Iowa Elec. Light \& Power Co. v. Atlas Corp., 467 F. Supp. 129, 140 (N.D. Iowa 1978) (52.2\% cost increase due to oil embargo and unexpected federal regulations held insufficient to 
between the binary alternatives of complete excuse or full performance. Indeed, the contingencies that justify excuse will always be foreseeable. After all, a rule excusing a burdensome performance is simply an implied force majeure provision that allocates the entire risk of a particular contingency to the buyer. Such a rule is the preferred strategy only in cases involving a known contingency that is beyond the seller's effective control. ${ }^{42}$ If the contingency is truly "unforeseeable," such that its probabilities or its effects cannot be assessed, then a risk-sharing rule generally will be preferred to either extreme of excuse or strict performance; parties would agree to excuse performance completely only in cases where the risks are, in fact, foreseeable. Given the decisionmaking strategies suggested by this analysis, therefore, the foreseeability test is incoherent. ${ }^{43}$

The second and potentially inore important implication of the analysis is that, regardless of the parties' efforts, the initial risk-distribution process will virtually always require adjustment to accommodate subsequent events. Even if a risk-allocation strategy is initially successful, subsequent events inevitably present opportunities for further improvements. Unfortunately, contracting parties cannot anticipate every adjustment that will be required. Furthermore, they cannot rely upon any metastrategy for selecting among different decision criteria over time. To be sure, when concerns about risk-allocation errors are sufficiently acute, the parties can always abandon the goal of long-term contracting and instead rely upon short-term or sequential contracts. But those parties who nonetheless anticipate substantial net econonies from long-term contracting will instead be motivated to rely on crude, teinporizing approximations of their risk-reduction objectives. Whether these initial assigninents will be appropriately adjusted in response to subsequent events thus depends on how those events affect the parties' relationship.

\section{Barriers to Ex Post Bargaining: The Adjustment Dilemma}

I assumed initially that the probability of any event or the magni-

excuse seller's performance), rev'd on other grounds, 603 F.2d 1301 (8th Cir. 1979), cert. denied, 445 U.S. 911 (1980); Publicker Indus. v. Union Carbide Corp., 17 U.C.C. Rep. Serv. (Callaghan) 989, 992 (E.D. Pa. 1975) (75\% cost increase allegedly resulting from OPEC cartel held insufficient to excuse seller); Eastern Airlines v. Gulf Oil Corp., 415 F. Supp. 429, 439-42 (S.D. Fla. 1975) (cost increases created by OPEC boycott, energy crisis, and federal controls were reasonably foreseeable); Center Garment Co. v. United Refrigerator Co., 369 Mass. 633, 637, 341 N.E.2d 669, 673 (1976) (failure of expected source of supply was foreseeable contingency borne by seller); Barbarossa \& Sons, Inc. v. Iten Chevrolet, 265 N.W.2d 655, 659 (Minn. 1978) (same); see also cases discussed in Stroh, supra note 1 , at 210-14.

42. See supra note 34 and accompanying text.

43. For a further discussion of the difficulties of the foreseeability test, see Sirianni, The Developing Law of Contractual Impracticability and Impossibility: Part I, 14 U.C.C. L.J. 30, 55-65 (1981). 
tude of its consequences remains constant throughout the contractual relationship. I now relax that assumption in order to analyze the influence of changing circumstances on the parties' contractual behavior. The seller and buyer face new problems as time passes and conditions change. Inevitably some contingencies become more (or less) probable, while others that were beyond calculation become more clear. Consequently, the initial risk allocation no longer represents the parties' best response to future continigencies.

Assume, for example, that Alcoa's production costs increase unexpectedly after $90 \%$ of the contract aluminum has been produced. If the parties can agree to adjust the contract quantity in light of these subsequent events they will reduce the joint cost of contracting. Once the contract has been made, however, Essex has little interest in voluntarily adjusting the contract to help reduce Alcoa's excess costs. But if Alcoa anticipates bearing excess costs, it will negotiate for a higher price to conıpensate for these additional costs. Both parties will gain if they agree in advance to adjust the mitial risk assignments so as to reduce expected future costs. ${ }^{44}$ Thus, both parties will probably adopt a broad statement of cooperative adjustment if they attempt to cope with this dilemma at all. The resulting risk-sharing agreement (which can take the form of a "good faith adjustment," "gross inequities," or "renegotiation" clause) ${ }^{45}$

44. Goetz \& Scott, supra note 24 , at 973.

45. Casual empiricism confirms the prevalence of renegotiation and other adjustment clauses in long-term contracts. These clauses have various designations, including "good faith adjustment," "gross inequities," and "market reopener." The unifying feature in all these clauses is the mutual obligation to adjust risks in light of subsequent events. See, for example, the following unsystematic sample:

(1) 1976 "OK-Tedi" copper agreement between the Government of Papua New Guinea and Dampier Mining Co., Ltd. (clause 42):

The parties may from time to time by agreement in writing add to, substitute for, cancel or vary all or any of the provisions of this Agreement ....

Quoted in W. PETER, supra note 2, at 154-55 (emphasis added by Peter).

(2) 1974 supplemental agreement to the 1960 "LAMCO" iron-ore agreement between the Republic of Liberia, the Liberian American-Swedish Minerals Co., and Liberia Bethlehem Iron Mines Co. (paragraph 24):

In case of profound change in the circumstances ... the parties, at the request of any one of them, will consult together for the purpose of considering such changes in or clarifications of this Mining Concession Agreement as the parties deem to be appropriate.

Quoted in id. at 155 (emphasis added by Peter).

(3) 1974 "Bougainville Copper" agreement between the Government of Papua New Guinea and Bougainville Copper Ltd. (clause 28B):

The parties shall co-operate with each other in carrying out the purpose of this Agreement and shall meet together during the seventh year after the year in which the Amendment Date oceurs .... They shall use their best endeavours to agree upon such changes in the Agreement as may be requisite.

Quoted in id. at 156.

(4) 1974 petroleum production agreement between the Government of Ghana and Shell Exploration and Production Co. of Ghana (clause 47b):

It is hereby agreed that if during the term of this Agreement there should occur such 
typically will require each contractor to extend whatever efforts are necessary to minimize the joint cost of responding to an adjustment crisis. ${ }^{46}$

But short-term considerations will continue to affect each party's calculations even after an exphicit agreement to adjust risk. Unless renegotiation would be mutually advantageous, the obhgee has no interest in reducing the obligor's costs and has little incentive to convey helpful information that might facilitate an adjustınent. By invoking the adjustment clause, the parties can attempt to reallocate the rights and duties that have become mefficient because of imtervening events.

Unfortunately, renegotiation creates an additional problem: The obhigee may bargam opportumistically in an effort to extract a premium for its cooperation. Noncooperative bargaining behavior can take a variety of forms-such as foot dragging or inflating estimates of the cost of adjustment-that are difficult to challenge directly. Moreover, the obligor may also threaten to evade the assigned responsibility altogether in order to induce cooperation at the minimum cost. ${ }^{47}$ Thus, the risk of exploitation prevents the parties from exclianging the information necessary for cooperative adjustments. ${ }^{48}$

The problems of renegotiation are acute because the parties will have become contractually specialized and lience will have substantially restricted options. Especially when magnified by strategic behavior, renegotiation costs impede readjustments that offer potential benefits to both parties. The parties must bargain in a more difficult environment, one tliat is likely to contain substantial barriers to negotiation and agreement. In many instances, especially where one party is threatened by substantial losses, the liigli cost of renegotiation may preclude effective bargaining over the appropriate responses to an adjustment contingency. ${ }^{49}$

changes in the financial and economic circumstances relating to the petroleum industry, operating conditions in Ghana and marketing conditions generally as to materially affect the fundamental economic and financial basis of this Agreement, then the provisions of this Agreement may be reviewed or renegotiated with a view to making such adjustments and modifications as may be reasonable having regard to the Operator's capital employed and the risks incurred by him ....

Quoted in id. at 158.

I analyze prototypical adjustment clauses and the limitations of their standard formulations in section IID2.

46. Goetz \& Scott, supra note 24 , at 973.

47. See Goetz \& Scott, supra note 24, at 982; Goetz \& Scott, supra note 9, at 1100-02; Klein, Crawford \& Alchian, Vertical Integration, Appropriable Rents, and the Competitive Contracting Process, 21 J.L. \& EcoN. 297, 298-302 (1978); Williamson, Transaction-Cost Economics: The Governance of Contractual Relations, 22 J.L. \& ECON. 233, 241-42 (1979).

48. See Goetz \& Scott, supra note 24, at 981-82.

49. An example of the phenomenon of renegotiation impasse may help to clarify this argument. Suppose an unanticipated contingency arises (e.g., a price increase in a factor of production) causing Seller a loss of $X$. Assume further that loss $X$ could be eliminated by reducing the quantity supplied under the contract, but that this reduction would cause a loss of $Y$ to Buyer. If 


\section{The Contractual Adjustment Process as a Cooperative Game}

The following analysis is an abstract formulation of the adjustment choices facing parties to long-term contracts. It illuminates the regulatory power of nonbargained patterns of reciprocal cooperation. In order to isolate the effects of patterned behavior in maintaining contractual relationships, I begin by assuming that the parties are completely unable to bargain. If the parties were absolutely precluded from renegotiating over adjustment they would find themselves in a classic "prisoner's dilemma." 50 In any given round of prisoner's dilemma, each party must decide whether or not to cooperate with the other. When both parties cooperate, each does well. There is, however, both a temptation to defect while the other party cooperates, producing a high payoff at the other's expense, and a fear that the other party will adopt a similar line of reasoning. Thus, a strict prisoner's dilemma game has a dominant strategy of noncooperation for at least one of the parties.

While noncooperative outcomes may often occur in contractual adjustments, they are not inevitable. The parties may still effectively commumicate even where they cannot bargain or renegotiate. For example, the parties may engage instead in a gane of "chicken," where the optimal choice between cooperation and noncooperation depends on the other party's actions. A chicken game involves bluffs or threats of noncooperation rather than a fixed noncooperative strategy.

The possibility of communication does not diminish the heuristic value of the prisoner's dilemma. All of the strategic-interaction games generate predictable and consistent patterns of noncooperation, patterns that can nonetheless be transformed to a cooperative equilibrium by continuous interaction. I will therefore use the prisoner's dilemma as a generic representation of any strategic-interaction game that results in systematic and predictable failures to cooperate. The discussion will

$X>Y$, Seller and Buyer ought to renegotiate-it is in both parties' interest that $X-Y$ be saved. Unfortunately, bargaining over distribution of the savings may be difficult. Negotiations may also be impaired because the residual loss ought to be borne by Seller. Furthermore, if no substitute goods are available elsewhere in the market, Seller may understate the magnitude of $X$ for fear that Buyer will demand too great a share of the savings.

50. Game theorists have developed the prisoner's dilemma problem to illustrate why, if parties are unable (for whatever reason) to communicate and bargain, they will systematically choose to pursue self-interested behavior, even though cooperation could advance their mutual interest. The mathematician A. W. Tucker initially developed the problem witl this scenario: Two prisoners are charged with the same crime and held in separate cells. If both remain silent they can be convicted only of a lesser offense and sentenced to one year. However, if one of them confesses, he is set free in exchange for his cooperation with the prosecutor. The prisoner who has remained silent is convicted because of the other's testimony and given a five-year sentence. If both confess, they will each be sentenced to three years. Thus, when one prisoner cannot know what the other will do, his safest course is to confess. But it is in their collective interest to remain silent.

An extensive literature explores this famous problem. For a general discussion, see R. LuCE \& H. RAIFFA, supra note 37, at 94-102. 
show that nonbargained patterns of cooperation can nonetheless develop in ongoing relationships in which parties have repeated opportunities to adjust cooperatively. Indeed, parties to long-term contracts can announce a precommitnient to cooperate conditionally and thereby encourage, even without numerous iterations, stable patterns of cooperative adjustnients. In turn, these patterns have powerful effects on real world contractual interactions where the parties do have the capacity to bargain.

\section{The Prisoner's Dilemma Heuristic}

A useful way to evaluate the consequences of barriers to renegotiation is to innagine that these barriers are absolute. Assume that Seller and Buyer, two large commercial firms, enter into a long-term supply contract. Subsequently, unanticipated labor problenis cause a teinporary increase in Seller's cost of producnig the contract goods. If the parties immediately cooperate (without bargaining) and adjust the contract to delay dehvery for three weeks, each will lose no nore than $\$ 20,000$. But if Seller evades by claiming that this event falls within the force n1ajeure clause, it will avoid all losses, and Buyer will lose $\$ 50,000$. If, on the other hand, Seller offers to cooperate, but Buyer insists that nonperformance is Seller's responsibility, then Seller will suffer a $\$ 50,000$ loss, and Buyer will incur no loss. Finally, if both continue to argue about responsibility, insist that the other is at fault, and ultimately seek a legal settlenient, then each-because of increased investinent in tinie and other costs-will lose $\$ 30,000$.

Visualizing this adjustnent opportunity as a strategic-interaction gaine such as a prisoner's dilemma illustrates why parties who are unable to communicate and bargain will systenatically choose to pursue their perceived self-interest, even though cooperative adjustnient would advance their mutual interest.

\section{FIGURE 1}

\begin{tabular}{c|c|c}
\hline \multirow{2}{*}{ SELLER BEHAVIOR } & \multicolumn{2}{|c}{ BUYER BEHAVIOR } \\
& ADJUST & EVADE \\
\hline ADJUST & $-20,000,-20,000$ & $-50,000,0$ \\
\hline EVADE & $0,-50,000$ & $-30,000,-30,000$ \\
\hline
\end{tabular}

Figure 1 presents the parties' responses to this adjustnient problen in a payoff matrix. Despite the parties' imitial commitnent to the primciple of cooperative adjustnent, a noncooperative outcone will result if the 
parties are unable to bargain face to face or to sign an enforceable agreement. Under these conditions, both parties predictably will act in their perceived self-interest, which will result in the worst possible outcome froin the perspective of their joint interests. This anomalous result occurs because neither one can affect the other's choice between adjustinent or evasion. Regardless of what the other party does, therefore, evasion is the preferable strategy if one is notivated by self-interest. If Seller evades and Buyer adjusts unilaterally, Seller loses zero. If Seller and Buyer both evade, each loses $\$ 30,000$. Alternatively, adjustment will cause Seller to lose either $\$ 20,000$ or $\$ 50,000$, depending on Buyer's choice. Since cooperation is less desirable no matter what Buyer does, Seller chooses evasion. Buyer, facing the same set of choices, makes the same decisions. Unhappily, therefore, both parties evade their responsibilities, the adjustment requires external intervention, and additional costs are incurred to resolve the dispute. In consequence, the parties collectively suffer $\$ 60,000 \mathrm{~m}$ losses, $\$ 20,000$ more than they would have lost if they had been able to reach the less costly solution of cooperative adjustment.

\section{The Discipline of Continuous Relations: Patterns of Conflict and Cooperation}

Despite the barriers that preclude bargained-for adjustment, patterns of cooperation can evolve among self-interested actors. ${ }^{51}$ Where Seller and Buyer are in an ongoing relationship, they face adjustment opportunities repeatedly. When the interaction between the two parties is iterated, the defecting choice inay no longer be the best choice. Because both parties have a stake in the future, the prospect of future interactions dramatically changes their adjustment strategies.

To test the potency of the long-term relationship, assume that: The relative payoffs from cooperation and evasion remain unchanged; neither party has recourse to legal or social mechanisms to make enforceable commitments; neither can affect the other's incentives to cooperate or not; and, neither can reliably predict what the other party will do in any given adjustment situation. ${ }^{52}$ Thus, Seller and Buyer can comınunicate

51. See generally R. AXELROD, supra note 8, at 3-24 (introducing the conditions giving rise to cooperation in an iterated prisoner's dilemma); sources cited infra notes 55-56.

52. The assumption that the parties are unable to predict each other's actions implies that they cannot rely on reputations derived from prior adjustment choices or contractual relationships. This assumption eliminates the "metagame" solution to the prisoner's dilemma in which each player, armed with a metastrategy of how best to play the game, can predict the move of his opponent and make the same choice the other is about to make. See N. HowARD, PARAdoxes of RATIONALITY: Theory of Metagames and Political Behavior 60-68 (1971). In Section ID3, I suggest precommitment as a variation on Howard's metagame solution. I relax the artificial assumption of total lack of reliable information in the discussion of information and enforcement defieits in Part II. 
only through their individual behavior when each adjustment choice is presented. Because the contract is long-term, each party retains the ability to evade or cooperate at subsequent adjustment opportumities. Consequently, in selecting an adjustment strategy, each party must consider the effect of its choice not only on the immediate conflict but also on later conflict situations. Thus, the future affects the present choice. ${ }^{53}$

Seller and Buyer might initially adopt widely differing decision strategies to meet the challenge of repeated interactions. A party may attempt to exploit its partner by consistently refusing to cooperate, or, conversely, it inay respond to any action of the other by adjusting cooperatively. Alternatively, either party may pursue a responsive or contingent strategy, one that varies between cooperation and evasion depending upon the actions of the other. ${ }^{54}$ For example, a strategy based on the principle of reciprocation, or "tit for tat," begins by cooperating with the other party when the first adjustinent choice is presented, and by emulating the other's actions in the previous interaction. ${ }^{55}$

The optimal adjustinent strategy in any interaction game of uncertain duration depends on the other party's strategy. Independent of the other party's strategy, no single method of decision is best. For instance, if Seller adopts a conciliatory strategy of unconditional cooperation, Buyer will eventually discover that his best strategy is to evade unconditionally. ${ }^{56}$ Alternatively, Buyer should unconditionally cooperate if Seller intends to cooperate only until the other defects.

Predicting the strategy of the other party is therefore an miportant aspect of developing one's own strategy. A good way to predict

53. See R. AXELROD, supra note 8 , at 12.

54. There are several classes of contingent strategies. In "state" contingencies, the strategy is based on a party"s response to four possible outcomes in the previous interaction. In "response" contingencies, the party's strategy is dependent or contingent on the other party's preceding response. See A. Rapoport \& A. Chammah, Prisoner's Dilemma 67-86 (1965).

55. The strategy of tit for tat is both the simplest and the most widely studied of the many response contingencies. The considerable experinental research on these response contingencies is summarized and analyzed in Downing, The Prisoner's Dilemma Game as a Problem Solving Phenomenon: An Outcome Maximization Interpretation, 6 SimUlation AND GaMEs 366 (1975). See, e.g., Axelrod, Effective Choice in the Prisoner's Dilemma, 24 J. Conflict Resolution 3, 6-7 (1980) (reporting a computer tournament in which tit for tat strategy won iterated prisoner's dilemma game); Bixenstine \& Gaebelein, Strategies of "Real" Opponents in Eliciting Cooperative Choice in a Prisoner's Dilemma Game, 15 J. CONFLICT RESOLUTION 157, 164-65 (1971) (cooperation enhanced by gradual rather than immediate shift to a $100 \%$-matching response); Wilson, Reciprocation and Other Techniques for Inducing Cooperation in the Prisoner's Dilemma Game, 15 J. CONFLICT Resolution 167, 172-73, 182-83 (1971) (tit for tat achieved greater cooperation than any other strategy studied).

56. The experimental results of $100 \%$-cooperation strategies are reviewed in Oskamp, Effects of Programmed Strategies on Cooperation in the Prisoner's Dilemma and Other Mixed-Motive Games, $15 \mathrm{~J}$. CONFLict Resolution 225, 237-42 (1971). In general, 100\% cooperation produced more defection than a purely responsive tit for tat strategy but less than an aggressive strategy of $20 \%$ cooperation. Id. at 237. 
responses is to assume that each party is trying to promote its own interest and that each believes the other party is intelligent and has similar goals. Under these circumstances, the parties may eventually learn to cooperate. In a trial and error process, the parties will eventually cooperate and thereafter be inclimed to persist because of the resulting steady positive payoffs. ${ }^{57}$ These payoffs contrast with the highly variant outcomes that occur when one party cooperates and the other evades. These outcomes are highly unstable because of the substantial disparity between one party's loss and the other's gain. Similarly, the harmfulness of the mutual-defection outcome stimulates the search for better strategies. ${ }^{58}$

The dynamics of repeated interactions of indefinite duration suggest, therefore, that a pattern of cooperative adjustment frequently will emerge. This prediction does not require that the parties be wholly rational decisionmakers. It assumes only self-imterested behavior played out im a variety of contexts. Each party adapts through trial and error to the strategy that seems to work best. ${ }^{59}$ Seller and Buyer inay each begin by evadimg adjustment responsibility. Over time, evasive strategies generate self-defeatmg "echo" effects, as the parties continually retaliate against the other's defection. Conversely, if one party begins by adjusting cooperatively and the other responds, inutual cooperation is introduced and then reinforced by a "lock-in" effect.

Empirical studies of cooperative interactions indicate that lock-in effects are very strong. ${ }^{60}$ These effects tend to make the parties behave like each other; the tendency is intensified as the interactions continue. Thus, if a pattern of cooperation can be established initially, a cooperative equilibriuin will emerge. Each party's self interest will induce it to maintain this productive pattern. ${ }^{61}$

57. Experimental research confirms this theoretical prediction. See Oskamp, supra note 56, at 237-42. Moreover, the experimental research strongly suggests that the patterning of cooperative responses has an effect independent of the level of cooperation. See id. at 239-42.

58. See A. RAPOPORT \& A. ChAmmah, supra note 54, at 53-55.

59. From the perspective of sociobiological theory, the manner in which cooperative behavior emerges is irrelevant if the parties successfully adapt to external constraints. A group of individuals who cooperate unconditionally will eventually be overrun by nonreciprocating eheaters. Conversely, unmitigated cheating will undermine any system of reciprocal relationships. Conditional reciprocity is thus a successful adaptation to the constraints of mixed-motive interactions characterized by both competition and cooperation. See Krebs \& Miller, Altrusion and Aggression, in 2 THE HANDBook of Social PSYChOLOGY 10-11 (G. Lindzey \& E. Aronson 3d. ed. 1985); Trivers, The Evolution of Cooperation, in The NATURe of Prosocial BeHavior: INTERdisciplinary THEORIES AND STRATEGIES 43 (D. Bridgeman ed. 1983). For a general discussion of the stability of tit for tat cooperation in a biological sense, see Axelrod \& Hamilton, The Evolution of Cooperation, 211 SCI. 1390 (1981).

60. See A. RAPOPORT AND A. ChammaH, supra note 54, at 65.

61. Luce and Raiffa define the cooperative pattern under these conditions as a "quasiequilibrium." It is in neither party's interest to initiate the punishing effects of mutual conflict, but the constant temptation to defect makes the pattern highly unstable. R. LUCE \& H. RAIFFA, supra note 37 , at 98 . 
Unfortunately, mutual cooperation is not the only entrenched equilibrium that can emerge from repeated interactions over adjustment opportunities. An inherent imstability exists in any prisoner's dilemma situation. If one party begins by evading the cooperative responsibility, the other may respond by retahating. Retaliation prompts a similar response, settimg off a series of mutual recrimmations. The "lock-in" effect, then, tends to push the parties toward either a stable pattern of tacit cooperation or the trap of mutual conflict. ${ }^{62}$

Indeed, there is no a priori reason why cooperation is more likely than conflict, since both equitibria can be rationalized. The mutual evasion trap seems imminently reasonable since neither party can rationally justify a unilateral move toward cooperation. For instance, if Seller cooperates unilaterally, Buyer can take maximum advantage of Seller. But the parties can also justify the alternative of tacit cooperation. If the pair has mutually cooperated, neither will resort to evasion because it would break up the mutually beneficial imteractions and result in a harmful cycle of retahation. ${ }^{63}$ Reahstically, the relative payoffs from cooperative and noncooperative responses will have an important influence on the outcome. The lower the returns from evasion relative to cooperation, the greater the probability of a cooperative equilibrium. Conversely, when the temptations to defect (and associated "sucker payoffs") are greater, the prospect of mutual conflict increases.

\section{A Precommitment Model of Contractual Cooperation}

The precedimg analysis suggests that repeated interactions between two parties will often stimulate patterns of mutual cooperation. But the cooperative outcome is not necessarily more likely than the other extreme of mutual conflict. This indeterminacy reveals the inherent instability of the parties' interactions when neither can predict the other's strategy choices nor influence the ultimate outcome by communicating a strategic intention to the other.

In a strict prisoner's dilemma, the strategies of the parties are absolute; secret commitments made without communication of intentions or midstream strategy changes. ${ }^{64}$ Thus, all strategies are equally plausible. But in long-term contractual relationships, commumication plays an important role even where the parties cannot bargain or renegotiate. In this environment, the strategies include promises or threats of future con-

62. Paradoxically, once interactive patterns have evolved, they generate an unstable environment "in which both the tendency to cooperate and to defect are 'self-propelling.'" A. RAPOPORT \& A. Chammah, supra note 54, at 134.

63. Id. at 65 .

64. See, e.g., Shubik, Game Theory, Behavior, and the Paradox of the Prisoner's Dilemma: Three Solutions, 14 J. Conflict Resolution 181, 188 (1970). 
duct. Each party must determine what plausible promises (or threats) will mduce the desired cooperation in the other party.

To understand this situation, we must relax the earlier assumption that neither party has the ability to predict the other's strategy choices. Assume, rather, that because the parties communicate, each one knows that the other can fairly predict the strategy it will choose. The surprising consequence is that, even without the prospect of repeated interactions, each party has an imcentive not to select the strategy of evasion. ${ }^{65}$

Recall the adjustinent/evasion matrix formulated in Figure 1. If Seller knows that Buyer will alınost surely evade, then Seller will also evade in order to prevent a $\$ 50,000$ loss. But if Seller knows that Buyer plans-at least provisionally-to adjust cooperatively, Seller may exploit this information by evading and thereby avoid any loss whatsoever. Given inutual predictability of choices, however, this tactic will fail. Buyer will anticipate Seller's plans to discontinue cooperative adjustment. Accordimgly, Buyer will retaliate and avoid suffering the $\$ 50,000$ loss by switching to a noncooperative response. Thus, Seller's attempt to exploit Buyer will fail and instead cause a $\$ 30,000$ loss for each party. Since both can predict each other's strategy choices, the temptations to evade are neutralized, thereby stabilizing the cooperative solution. ${ }^{66}$

Under conditions of inutual predictability, therefore, either party can induce a cooperative equilibrium in the very first interaction by announcing its intention to cooperate conditionally before making an adjustment choice. The precommitınent to cooperate is a reliable promise; each party knows it cannot, with inipunity, suddenly switch strategy choices once adjustment options are presented. Thus, the responding party will maximize its respective utility by also cooperating. The precommitnient strategy facilitates the coninencenient of a cooperative pattern. ${ }^{67}$ Thereafter, in an ongoing relationship with repeated interactions, both parties will "lock $\mathrm{m}$ " the cooperative equilibriun1. ${ }^{68}$

The success of precoinnitment depends upon each party's ability to predict the other's strategy choice accurately. If a party doubts the accuracy of its prediction, it will be tenipted to "test" the other's resolve by occasionally behaving noncooperatively. Inıniediate retaliation niay seen1 an overly harsh response to such a test and one unlikely to convey the mitiator's bemign intentions. A niore conciliatory response-such as

65. Steven Brams first proposed the significance of mutual predictability and the cooperative solution that it suggests. See Brams, Newcomb's Problem and Prisoners' Dilemma, 19 J. CoNflict RESOLUTION 596, 603-04 (1975).

66. Id. at 604 .

67. Pilisuk \& Skolnick, Inducing Trust: A Test of the Osgood Proposal, 8 J. Personality \& Soc. PsYchoLogY 121, 133 (1968).

68. See Wilson, supra note 55, at 186 (discussing the value of precommitment combined with prompt and consistent reciprocation). 
a gradual or delayed retaliation-may seem more conducive to stable cooperative interactions. Conciliation, however, creates the risk that the inducing party's behavior will be incorrectly imterpreted as unconditional unilateral cooperation and thus exploitable by more aggressive behavior. ${ }^{69}$ However well-intentioned it may be, a conciliatory response could undermine the plausibility of a claimed precommitment to conditional cooperation. ${ }^{70}$ This problem results from tlie crucial requirement of predictability. A precommitment strategy requires a party to make its own behavior predictable and anticipates adjustment from the otlier. ${ }^{71}$

Tlie propensity to pumish evasion inust be teinpered, liowever, by an equivalent propensity to forgive noncooperative behavior. A party committed to a policy of conditional cooperation retaliates, but returns to a cooperative response at the next opportumity. ${ }^{72}$ Viewed ex post, a willingness to continue cooperation despite betrayal might be characterized

69. See R. AXELROD, supra note 8, at 184-87. One of the dangers of being slow to respond to unprovoked defections is the risk of sending the wrong signal. See infra Section IIA1. For empirical studies of the consequences of being "slow to anger," see Bixenstine, Potash \& Wilson, Effects of Level of Cooperative Choice by the Other Player on Choices in a Prisoner's Dilemma Game, Part I, 66 J. Abnormal \& Soc. Psychology 308, 312 (1963); Bixenstine \& Wilson, Effects of Level of Cooperative Choice by the Other Player on Choices in a Prisoner's Dilemma Game, Part II, $67 \mathrm{~J}$. ABNormal \& Soc. PsYchology 139, 147 (1963) (subjects exploited the party who used a highly cooperative strategy). Research findings generally support the conclusion that "[a] contingent strategy, such as TFT [tit for tat] matching, produces significantly higher concurrent cooperation than a noncontingent strategy having the same level of cooperation." Oskamp, supra note 56, at 246.

70. Investigators have studied various conciliatory variations on the basic principle of reciprocation. For example, in laboratory tests with 500 subjects, Wilson discovered that pure reeiprocation (such as tit for tat) produced more cooperation than several conciliatory variations that attempted to coax the other party out of a consistently competitive pattern. Wilson, supra note 55, at 182-84; see also Deutsch, Epstein, Canavan \& Gumpert, Strategies of Inducing Cooperation: An Experimental Study, 11 J. CoNflict Resolution 345, 354-59 (1967) ("deterrent" strategy more effeetive than "turn the other cheek" strategy); Komorita, Cooperative Choice in a Prisoner's Dilemma Game, 2 J. Personality \& Soc. Psychology 741 (1965); McClintock, Gallo \& Harrison, Some Effects of Variations in Other Strategy Upon Game Behavior, 1 J. Personality \& Soc. Psychology 319, 322-24 (1965); Scodel, Induced Collaboration in Some Non-Zero Sum Games, 6 J. CoNflict Resolution 335, 338-39 (1962).

These investigators found that a tit for tat strategy, or a close variation, results in more mutual cooperation than other contingent strategies, noncontingent strategies, or natural play. But see Oskamp \& Perlman, Factors Affecting Cooperation in a Prisoner's Dilemma Game, $9 \mathrm{~J}$. CONFLICT RESOLUTION 359, 365 (1965) (finding that a tit for tat strategy produced no more mutual cooperation than an unconditionally cooperative strategy).

71. Predictability implies that a party will reciprocate either cooperation or competition promptly and consistently. This does not mean that an impulsive retaliation is necessarily superior to a measured response that reciprocates only after the other's defection is clear. But the principle of reciprocation does require both predictability and contingency in order to successfully elicit a cooperative pattern. See Wilson, supra note 55, at 186; see also Hoedemaker, Distrust and Aggression: An Interpersonal-International Analogy, 12 J. CONFLICT RESOLUTION 69, $70-72$ (1968); Sawyer \& Guetzkow, Bargaining and Negotiation in International Relations, in INTERNATIONAL BeHAvior 466 (H. Kelman ed. 1965).

72. See R. AXELROD, supra note 8, at 36 (defining forgiveness as the propensity to cooperate in the suceeding move after the other party has defeeted). 
as "martyrdom" or "stupidity."73 But the precommitment model has an ex ante focus. Thus, forgiveness reflects a belief in the power of teaching by example. By the simple expedient of punishing evasion and rewarding cooperative adjustment, a party assuming a leadership role can "bring out the best" in the other and thereby reinforce the cooperative cquilibrium.

Parties to long-term contracts should be able to announce a precommitment to conditional cooperation and thereby encourage a stable pattern of cooperative adjustment. Nevertheless, contractual breakdowns frequently occur. Determining whether a cooperative game model is a useful framework for analyzing real-world contracting behavior thus requires a more complex and texturcd analysis. My analysis to this point has set aside important variables that frequently occur in actual contractual imteractions. In Part II, therefore, I introduce more realistic assumptions in order to isolate the conditions that can undermine patterns of cooperation. I then evaluate the various legal and extralegal mechanisms that contracting parties use to reinforce their cooperative strategies.

II

The Dynamics of Risk Allocation and AdJustment IN LONG-TERM CONTRACTS

The game theoretic model in Part I unrealistically assumed that the parties' adjustment choices can be costlessly interpreted as either cooperative or evasive, and that both cooperative and retaliatory reactions can be costlessly enforced. In fact, acquiring information about the other party's actions and implementing an appropriate response are both costly and potentially fallible. Information problems are often exacerbated in real-world contractual interactions by genuine uncertainties as to the other party's actions during the previous adjustment crisis.

Furthermore, the various incentives to cooperate or evade do not remain constant over a continuous (presumably infinite) series of interactions. A more realistic analysis, then, must consider two additional variables: (1) each party's discount rate (that is, the rate at which the present value of future payoffs decreases when projected into the future); and (2) the exogenous probability that the interactions will terminate after a fimite time. These variables introduce additional instabilities that threaten emerging patterns of cooperation.

The cooperative game model also was unduly restrictive in its assumptions about how parties might respond to information and enforcement deficits. It assumed that the parties could not rely on prior

73. See A. Rapoport and A. Chammah, supra note 54, at 72 . 
reputation and interactions with others to predict the likely strategy of prospective contractors. Moreover, it assumed that the parties did not have any mechanisms, otler tlian the "discipline of continuing dealings," for enforcing their initial commitment to cooperative adjustment.

In the following sections, I will relax eacli of these assumptions in order to examine botll the problems caused by information and enforcement deficiencies and the range of mechanisms parties can use to overcome tliem.

\section{A. The Problem of Information Deficiencies}

Selecting an appropriate strategy for adjusting contract risks becomes more complicated when the contracting parties' behavior cannot be readily understood. This problem is particularly acute in the context of contractual evasion. Parties rarely evade by directly announcing their unwillingness to cooperate. They typically affirm solidarity, protest helplessness in the face of intractable problems, or act in subtle ways that are difficult to evaluate. Similarly, cooperative actions can also be nisunderstood, especially if the ideal cooperative response is not immediately apparent to the other party. For instance, the cooperative response to Seller's increased production costs may be for Buyer to sliut down rather than to follow Seller's request and temporarily relocate production into otlier contracts. Indeed, a contracting party may not realize until mucl later the appropriateness (or inappropriateness) of its partner's response. $^{74}$

\section{Extralegal Responses to Information Deficits: Reputation and Other Signaling Mechanisms}

There are several ways to reduce the costs of acquiring information concerning the actions of a contracting partner. For instance, an established reputation raises the inference that observed belhavior will be repeated in future transactions. ${ }^{75}$ Prior knowledge about the strategy a

74. Background "noise" or systematic misperception of the other's actions might cause information deficiencies. Misperception may stem from cognitive errors-e.g., relying on a small sample size to characterize the other party's behavior. $C f$. $R$. Jervis, Perception AND Misperception IN INTERnational Politics (1976) (discussing the effects of misperception in international relations).

75. If the market for contracting partners is "thick," fear of the prisoner's dilemma diminishes because each party has a strong desire to establish its credibility so that it can engage in future contractual relationships. Thus, the key variable in the well-developed market is each party's ability to choose its own partners. See Tullock, Adam Smith and the Prisoner's Dilemma, 100 Q.J. EcoN. 1073, 1076 (1985). But see Klein \& Leffler, The Role of Market Forces in Assuring Contractual Performance, 89 J. POL. ECON. 615, 618-25 (1981) (showing that even in a competitive market, reputation, goodwill, and the benefits of repeat business do not completely deter the temptation to evade).

In the specialized "thin" market of the long-term contract, where the choice among contracting 
party is likely to pursue reduces the relative importance of characterizing each subsequent interaction accurately.

But a prior reputation can also be an impedinent. By revealing one's likely future actions, a reputation exposes a party to exploitation. Fear of exploitation may, in turn, lead to costly defensive maneuvers that reduce the value of the reputation. Contracting parties have an incentive, therefore, to develop a reputation that botli encourages mutually beneficial cooperation and deters exploitation. ${ }^{76}$ Once again, a precommitinent to reciprocity resolves this dilemma. A reputation for adhering to conditional cooperation offers the best chance of overcoming the threat imposed by inadequate mformation. A strategy that promises iminediate retahiation cannot be readily exploited. Moreover, conditional cooperation fosters interparty cooperation and (perhaps most importantly) sends an unambiguous sigual to both existing and potential future contracting partners.

Reputation itself is costly. To reduce the costs of acquiring a cooperative reputation, contracting parties use various signaling mechanisms. One such device is "labeling"; basing assumptions on fixed characteristics of other parties that can be easily observed when the interaction begins. Janet Landa has demonstrated the value of labeling for ethnically hoinogeneous Chinese middleinen who pursue cooperative strategies based on fixed and inmutable characteristics such as familial identity and dialect. ${ }^{77}$ Since the familial relationship reflects a pre-established and lighly effective system for enforcing group norms, this status carries a umque guarantee of inutual cooperation. Although few such unambiguous labels are likely to be available to most cominercial contractors, there are substitute metliods of status identification. For instance, cominercial parties often form trade associations that promulgate ethical

partners is limited, reputational concerns are much less potent. Rights accrued under a long-term contract with little likelihood of replication may be more valuable than a general reputation for cooperation. See Goetz \& Scott, supra note 24, at 1013.

76. Several studies establish the relevance of a prior reputation for being trustworthy. Merton Deutsch first identified the significance of trust in influencing the outcome of prisoner's dilemma games. See Deutsch, Trust and Suspicion, 2 J. CoNflict REsolution 267 (1958). Absent trust, one party can undermine an emerging pattern of cooperation by viewing the other's cooperative behavior as a subtle trap or deception. Indeed, investigators have shown that credible promises (those made by parties historically known to keep their word) induce more cooperation than promises made by parties with no established reputation. See Gahagan \& Tedeschi, Strategy and the Credibility of Promises in the Prisoner's Dilemma Game, 12 J. CONFLict Resolution 224, 229-31 (1968); Horai \& Tedeschi, Effects of Credibility and Magnitude of Punishment on Compliance to Threats, 12 J. Personality \& Soc. Psychology 164, 168-69 (1969) (more credible threats also effective in generating patterns of cooperation). On the general question of the importance of making cooperation and punishment predictably contingent on the other party's response, see $R$. AXELROD, supra note 8, at 118-23.

77. Landa, A Theory of the Ethically Homogeneous Middlemen Group: An Institutional Alternative to Contract Law, 10 J. LeGAL STUD. 349, 358-60 (1981). 
norms for contracting behavior. While members of trade organizations are not as tightly bonded as Chinese middlemen, membership does offer useful signals to other contractors. Similarly, while bonds of trust and confidence generated by family status cannot be replicated in cominercial settings, parties can adopt territorial strategies using a pattern of trade with "neighbors" as a substitute signaling technique. ${ }^{78}$

Where Seller and Buyer cannot rely on prior reputation or labeling, they can signal their future behavior by using individualized or transaction-specific devices. One such device is offering to pledge assets as collateral for the promise of subsequent cooperation. ${ }^{79}$ Alternatively, a party can agree to pay a substantial penalty for a breach of its obhigation to adjust cooperatively. Both devices signal a party's resolve to adjust according to the pre-committed pattern of conditional cooperation. ${ }^{80}$ Even without a legally enforceable contract, self-enforcing systems (such as third-party stakeholders) can reinforce such commitments.

The preceding discussion has focused on the value of a reputational signal when the parties are engaged in continual imteraction. Now consider the case of a fimite interaction between the parties. If the parties know in advance the termination point of their relationship, they confront a well-known "end-game" problem that threatens cooperation in the iterated prisoner's dilemma. Because cooperation will no longer be beneficial at the last adjustment opportunity, a party will be motivated to evade and capture its largest payoff. Anticipating that response, the other party has a similar incentive to evade at the next to the last opportunity (its own last opportunity for choice). Anticipating this, the other party evades at his previous opportunity and so on. Following this logic, the cooperative solution to the entire sequence unravels. ${ }^{81}$

Fortunately, parties cannot accurately predict the number of interactions in most long-term contracts in advance, so the threat of a cooperative pattern unraveling is implausible. However, some parties to a longterm contract do approach a definite termination point (for example, the end of a twenty-year term). In order for the sequence of cooperation to reinain stable, each party must be assured that the other's commitment to cooperate will continue until the end of their relationship.

78. R. AXELROD, supra note 8, at 158-68.

79. See Kronman, Contract Law and the State of Nature, 1 J.L. Econ. \& ORganizations 5, $12-15$ (1985).

80. See Scott, A Relational Theory of Secured Financing. 86 Colum. L. Rev. 901, 928 (1986) (discussing security interests as means of encouraging cooperation between certain debtors and creditors).

81. See R. Luce \& H. RAIFFA, supra note 37, at 98-101. The fact that the utility-maximizing logic of the problem leads to "unreasonable" results (in which "stupid" players end up doing much better than "smart" ones) is a criticism of the repeated prisoner's dilemma as a complete normative theory. Indeed, the empirical results demonstrate that strong patterns of mutual cooperation emerge even in the game with many trials. See A. RAPOPORT \& A. Chammah, supra note 54, at 66. 
One method of signaling a resolve to cooperate is to develop a general reputation for altruisin. When a party is known to be cooperative despite self-interest, the other will not fear evasion in the last stages of the relationship and thus will not take defensive actions. ${ }^{82}$ Alternatively, a self-interested cominercial party can achieve the same outcome by developing a reputation for conditional cooperation. For example, if Seller has resolved always to follow a principle of reciprocation (cooperating initially, but thereafter adjusting only for those who cooperate in return), Seller will develop a reputation of never being the first to evade. Seller can maintain this reputation only by refusing to evade even at the last opportunity of a particular relationship. Such a reputation will induce Buyer to maintain cooperative responses throughout the relationship. ${ }^{83}$ A reputation for conditional cooperation is an effective antidote to the end-ganie problem in contractual settings because contracting parties can choose their own partners. Thus, reputation is valuable for future as well as present relationships.

\section{Reducing Adjustment Uncertainty: The Effects of Legal Signals}

The preceding discussion suggests that the ability of contracting parties to achieve a cooperative equilibrium depends significantly on the clarity and predictability of the extralegal signals they use to convey their intentions. In addition, legal rules anehorate the problems of imperfect information.

The relationship between legal and extralegal mechanisms can be clarified by isolating the two crucial periods of information exchange in the contracting process: initial risk allocation and adjustment. During the adjustment period, reputation and other extralegal devices are the principal means of reducing the effects of information deficits. At this stage, legal regulation plays only a supplemental role in ensuring the general quality of these signals. ${ }^{84}$ The law has a nuch inore pervasive function, however, in reducing information deficiencies that impair the initial

82. Cf. Becker, Altruism, Egoism and Genetic Fitness: Economics and Sociobiology, 14 J. EcoN. LITERATURE 817, 822 (1976) (explaining interaction between altruists and egoists as leading egoists to simulate altruists); Hirshleifer, Shakespeare vs. Becker on Altruism: The Importance of Having the Last Word, 15 J. Econ. LITERATURE 500, 501 (1977)(noting some limitations of Becker's model).

83. Ronald Wintrobe argues that a strategy based on reciprocity is as effective as purc altruism in solving end-game problems. He also argues that it is much less costly, since the altruist continues to make donations to evaders while the party adopting conditional cooperation will retaliate-to reduce his loss. Wintrobe, It Pays To Do Good, But Not To Do More Good Than It Pays, 2 J. Econ. BeHAVIORAL ORganization 201, 211-12 (1981).

84. The law of fraud, prohibitions against false and deceptive advertising, and the protection of trademarks all enhance the reliability of reputational signals. See generally E. KITCH \& H. Perlman, Regulation of the Competitive Process: Cases, Materials and Notes 54-83, 253-76 (3d ed. 1986) (discussing legal regulation of information through laws governing false or deceptive advertising and trademark protection). 
risk-allocation process. Contractual terms that distribute risks are signals designed to achieve various specific purposes. If these signals have been inadequately designed or tested, they invite misunderstanding, disagreement, and, ultimately, inutual conflict. ${ }^{85}$

At the mitial risk distribution stage, contract law offers two valuable tools-the implied term and the express invocation-that, singly or in combination, reduce errors and uncertainties in the initial agreement. The implied term is the primary instrument for reducing errors in contract formulation. ${ }^{86}$ By implying preformulated terms into the basic agreement, the law suppties useful standardized risk assignments. ${ }^{87}$ Common law "rules" provide for nnany of the basic details of any contractual relationship, including the timing, sequence, and standards of performance. These rules consciously reflect dominant and evolving conceptions of how similarly situated parties can be expected to assign risks if required to bargain explicitly in advance. ${ }^{88}$

Judicially developed risk allocations have proved remarkably durable. The risk-control criterion, for exainple, was first announced in 1647 in Paradine v. Jane. ${ }^{89}$ Furthermore, judicially created implied terms have been designed to accommodate diverse contractual environments. For exainple, the two contrasting performance standards-perfect tender and substantial performance-reflect a skillful accommodation of variations in the market for substitute performances. ${ }^{90}$

85. Goetz \& Scott, The Limits of Expanded Choice: An Analysis of the Interactions Between Express and Implied Contract Terms, 73 CALIF. L. REv. 261, 265-66 (1985).

86. Formulation errors are implementation mistakes-such as ambiguity, incompleteness, inconsistency, and distortion-that result in contract terms that deviate from the subjectively desired exchange. The costs of such errors include the failure to fully exploit contractual opportunities and the unintended necessity of having the state interpret disputed contracts. Id. at 265-68.

87. Goetz \& Scott, supra note 21 , at 588 n.87.

88. "[T]he common rules have been worked out by common sense, which has established what the parties probably would have said if they had spoken about the matter." Globe Refiniug Co. v. Landa Cotton Oil Co., 190 U.S. 540, 543 (1903) (Holmes, J.).

89. Paradine v. Jane, Aleyn 26, 27, 82 Eng. Rep. 897, 897 (K.B. 1647) ("When the party by his own contract creates a duty or charge upon himself, he is bound to make it good, if he may, notwithstanding any accident by inevitable necessity, because he might have provided against it by his contract.").

90. Sometimes sellers prefer a standard of substantial performance rather than strict performance. A seller of construction services, for example, would dislike a strict standard because requiring perfection could cause a substantial loss of the purchase price due to merely trivial defects. Similarly, the builder could not feasibly "take his house back" if the owner decides to reject because of a faulty latch. The parties to construction contracts, therefore, would presumably negotiate for a rule of substantial performance in good faith, and this what the law requires. See Goetz \& Scott, supra note 24 , at 1009-11.

Rejection imposes much lower costs on sellers in sales contexts than iu construction contracts. The perfect tender rule apparently reflects the result that parties to sales contracts would reach were they to bargain over rejection. Buyers normally prefer to pay only for conforming goods. Rejection leaves a seller with the goods, which can be repaired and resold at the market price or sold immediately at a price that reflects their (slightly defective) condition. Id. 
But even the most skillful judicial craftsmen can construct implied terms only through the slow, evolutionary process of common law adjudication. Accordingly, contract law has increasingly turned to the contractual environment to supply implied terms. Custoin, usage of trade, and other experiences between similarly situated contractimg parties offer a rich source of common patterns for distributing and adjusting risks. ${ }^{91}$ A doininant trade usage within a particular industry will constitute an implied term for all transactions within the relevant category. The contractual environment thus supphies some inature, tested risk assignments that the "individual parties could not replicate merely by the expenditure of additional time and effort."

Implied terms provide contractimg parties a foundation of reliable signals for distributing risks. Particular circumstances, however, will require expressly negotiated alternatives that supersede the implied terms. The state may nonetheless play a role in the parties' choice of individualized arrangeinents. Courts are more likely to misinterpret an agreement that combines individually negotiated provisions with customary terms.

The uncertainty over judicial interpretation may actually exacerbate imperfect signaling of the parties' risk distribution preferences in the initial agreement. For example, in one case contracting parties agreed to a price term with an escalation clause that provided: "In no event . . . shall

91. These customary terms include trade usages regarding the existence of warranties, see U.C.C. $\$ 2-314(3)$ comment 3 (1978); commonly accepted quality tolerances, see, e.g., Ambassador Steel Co. v. Ewald Steel Co., 33 Mich. App. 495, 499, 190 N.W.2d 275, 278-79 (1971); and circumstances under which apparently fixed price and quantity terms are in fact subject to some variation, see, e.g., Columbia Nitrogen Corp. v. Royster Co., 451 F.2d 3, 9-10 (4th Cir. 1971).

92. Goetz \& Scott, supra note 85 , at 278 ("[T]he process of contractual formulation is subject to inherent endogenous hazards that emerge and undergo correction only over time. Accumulated experiences are thus very important in shaping customary contractual prototypes." Id.)

An instructive example of the evolution of implied terms is the "best efforts" standard that regulates the quantity term in exclusive dealings contracts. Initially, common law courts, citing the absence of a definite quantity term as evincing an illusory obligation, declined to enforce exclusive dealings agreements. See, e.g., Bay v. Bedwell, 21 S.W.2d 203, 205 (Mo. Ct. App. 1929); Barton v. Spinning, 8 Wash. 458, 460, 36 P. 439, 440 (1894) (listing early cases). Thereafter, in Wood v. Lucy, Lady Duff-Gordon, Judge Cardozo, finding such arrangements "instinct with an obligation" created the "best efforts" implied term. 222 N.Y. 88, 91, 118 N.E. 214, 214 (1917). In the following 70 years, courts have constructed an increasingly coherent best-efforts jurisprudence, relying on evidence of customary contractual relationships and using the benchmark of the integrated firm to define the performance obligation. See, e.g., Bloor v. Falstaff Brewing Corp., 601 F.2d 609, 614 (2d Cir. 1979) (enforcing best-efforts obligation against the licensee-distributor by awarding damages projected from the behavior of "comparable" brands marketed by other distributors); Contemporary Mission, Inc. v. Famous Music Corp., 557 F.2d 918, 923 (2d Cir. 1977) (music publishing); Perma Research \& Dev. v. Singer Co., 542 F.2d 111, 115 (2d Cir.) (patent licenses), cert. denied, 429 U.S. 987 (1976); Van Valkenburgh, Nooger \& Neville, Inc. v. Hayden Publishing Co., 30 N.Y.2d 34, 281 N.E.2d 142, 330 N.Y.S.2d 329 (1972) (book publishing). 
the ... increase in the contract price . . exceed the price histed below."93 The parties apparently beheved that the limited escalator merely supplemented the standard implied term that performance would be excused entirely if adversely affected by unforeseeable circuinstances. The court 1mistakenly interpreted this effort as an attempt to countermand the doctrime of excuse altogether. As a consequence, when the price adjustment mechanisin failed, the court assigned to the performing party both foreseeable and unforeseeable risks. In the resulting conflict, the relationship disintegrated. ${ }^{94}$

A second legal nechanisin, the express invocation, can help to clarify these uncertain signals. An express invocation is a term that carries a legally unainbiguous meaning that the courts will strongly, perhaps even irrebuttably, presuine. ${ }^{95}$ The legal recognition of certain talisnianic words and phrases greatly facilitates parties' atteinpts to integrate the express and implied terms of their agreement. This benefit has inotivated parties to use a variety of internationally recognized force inajeure and coniniercial frustration clauses to govern certain types of long-term contracts. ${ }^{96}$ Ideally, contracting parties should be able to pick and choose anıong a predetermined inenu of such standardized express terms in order to construct an unambiguous risk-allocation schenie. ${ }^{97}$

Unfortunately, while standardization of terms reduces the uncertainty associated with complex risk assignments, it also impedes experinientation with innovative arrangenents. Contracting parties are likely to encounter substantial probleins when they seek to develop innovative agreenients for distributing risk. In the first place, they inay have difficulty escaping the standardized arrangenients since any interpretive disagreenients are likely to be resolved by judicial recourse to the very sanie

93. Publicker Indus. v. Union Carbide Corp., 17 U.C.C. Rep. Serv. (Callaghan) 989, 990 (E.D. Pa. 1975).

94. Id.; see also Missouri Pub. Serv. Co. v. Peabody Coal Co., 583 S.W.2d 721, 728 (Mo. Ct. App.) (seller's claim of excuse denied because seller "agreed to the use of the Industrial Commodities Index Factor"), cert. denied, 444 U.S. 865 (1979).

95. Although "[d]efinitional recognition does not change the optional character of these express terms," it does serve to standardize the terms' meaning regardless of the context in which they are employed. Goetz \& Scott, supra note 85, at 282.

96. See, e.g., United Nations Conference ou Contracts for the International Sale of Goods (Vienna 1980) art. 79, reprinted in LEGAL ASPECTS OF INTERNATIONAL BUSINESS TRANSACTIONS 307, 355 (D. Campbell \& C. Rohwer eds. 1984); Convention Relating to a Uniform Law on the International Sale of Goods (The Hague 1964) art. 74, reprinted in I SouRCES OF INTERNATIONAL UNIFORM LAW 41, 55 (K. Zweigert \& J. Kropheller eds. 1971); General Agreement on Foreign Trade (GAFTA) model contract 100 , clause 22:

Force majeure strikes, etc.-seller should not be responsible for delay in shipment of the goods ... occasioned by any Act of God, strike, lockout, riot or civil commotion, combination of workmen, breakdown of machinery, fire or any cause comprehended in the term force majeure. . . .

97. "The state's recognition of the evolutionary trial and error process functions as a regulatory scheme designed to promote these "public goods." " Goetz \& Scott, supra note 85, at 286. 
context that contractual innovators seek to escape. ${ }^{98}$ As a consequence, the state's institutional support for implied terms results in a bias against unconventional expressions. ${ }^{99}$

Furthermore, even assuming the parties to one contract can create new contractual language that will escape the problems of conventional implied terms, the parties may be unable to coordinate adoption of the new arrangement by other contractors. ${ }^{100}$ The state's control of the meclianism by which such contract terms are officially recognized makes private efforts more risky than using the existing standardized terms and serves, on balance, to retard the evolutionary process. ${ }^{101}$

In sum, a paradox underlies the parties' reliance on the law of contract to signal their risk allocation objectives. The very rules that facilitate complex risk-distribution strategies serve a largely unrecognized regulatory function as well. These customary allocations retard the parties' ability to develop innovative risk-distribution schemes, despite new or emerging business needs. Furthermore, the state's control over the interpretation process restrains already weak market forces that might encourage innovation. Thus, despite the use of legally standardized signals, the precise intentions of parties to long-term contracts may remain

98. A number of recent cases demonstrate the difficulty of using express terms to countermand ill-fitting implied terms. See, e.g., Nanakuli Paving \& Rock Co. v. Shell Oil Co., 664 F.2d 772, 782 \& n.14 (9th Cir. 1981) (merger clause, excluding evidence of prior dealings, does not bar introduction of usage of trade to alter price term in the contract); Steuber Co. v. Hercules, Inc., 646 F.2d 1093, 1096-98 (5th Cir. 1981) (evidence of course of performance held to vary normal meaning of C.I.F. term in written contract); Brunswick Box Co. v. Coutinho, Caro \& Co., 617 F.2d 355, 360 (4th Cir. 1980) (same, F.A.S. term); Legnos v. United States, 535 F.2d 857, 858 (5th Cir. 1976) (despite express term "F.O.B. Vessel" in the contract, international context requires that "the intention of the contracting [parties], rather than definitional niceties, must be given controlling weight").

99. See Goetz \& Scott, supra note 85 , at 290-91.

100. A transition to new contract terms incurs two distinct types of costs. First, the parties must bear the costs of innovation, which include identification of terms that have potential advantages over the status quo. The lack of copyright protection for such contract terms means that the first set of costs will not reliably be recaptured by the innovator. See Goetz \& Scott, supra note 85, at 292; cf. Morrissey v. Procter \& Gamble Co., 379 F.2d 675, 678 (1st Cir. 1967) (particular form of contest rule is uncopyrightable if the idea is so straightforward or narrow that there are only a limited number of ways to express it).

Second, when the advantages of the new terms depend on standardization, groups of contracting parties must coordinate joint adoption of a standard formulation of the new arrangement. No single contractor is likely to fully capture the benefits of coordination becausc these benefits depend on "agglomeration economies"; that is, other parties must make the move in sufficient numbers to yield advantages from standardization. See Goetz \& Scott, supra note 85, at 291-93.

101. Over time, the state-supplied [risk assignments] will themselves fail to evolve because the flow of innovative formulations, express and implied, will dwindle. The raw material from which preformulations emerge consists of the expressions and experiences of individual bargainers confronting new and challenging contractual problems. If that trialand-error experience is diminished because parties turn to convenient standardized terms offered by the state, the evolutionary process itself stagnates.

Goetz \& Scott, supra note 85 , at 289. These barriers to innovative strategies for distributing risks are a byproduct of the state's regulation of standard risk allocation arrangements. 
uncertain. Nevertheless, legal signals do promote a sense of predictability, which is essential to any cooperative equilibrium.

\section{B. The Enforcement Dilemma}

Predicting the adjustment strategy of a contractimg partner is hampered further by efforts to disciphine uncooperative behavior. Ideally, a single retahiatory response of equal consequence can deter occasional instances of noncooperation. Thus, where constant payoffs recur at regular intervals, the principle of reciprocation through contmuous dealings is entirely self-enforcing.

In the more realistic case, the intervals between adjustment choices and the levels of reward and pumishment vary. Under these conditions, the parties must turn to supplemental enforcement systems in order to maintain the relative advantages of long-term cooperation over shortterm evasion. Each party can threaten retaliation to insure that the other will properly internahize the joint costs of mutual conflict. To be effective, however, the proposed threats must be both carefully calibrated and credible. Credibihity, in turn, requires both ex ante commitment and ex post sanctions.

\section{Extralegal Enforcement Mechanisms \\ a. Self-Enforcing Agreements}

- Many of the mechamisms that serve an ex ante sigualing function also serve an ex post enforcement purpose. For example, the threat of forfeiting a bond or a pledge of security may induce a party to commit to a strategy of conditional cooperation. While the coercive effect of security interests or penalty bonds derives from legal recognition, once created these devices are largely self-enforcing. Thereafter, the selfenforcing security interest or penalty bond functions as a credible commitment, binding the promisor to a predictable pattern of future behavior. ${ }^{102}$

This use of contractual sanctions must, however, be carefully calibrated to ensure a stable cooperative equilibrium. Suppose, for instance, that Seller offers Buyer assets as a "hostage" to insure Seller's compliance with an agreement to adjust cooperatively. If the hostage assets have a ready resale value, then Buyer will have a perverse incentive to induce a breach, declare default, and sell the assets. Ideally, the hostage

102. See Scott, supra note 80 , at 928 n.90; see also Grossman \& Hart, Corporate Financial Structure and Managerial Incentives, in THE ECONOMICs OF INFORMATION AND UNCERTAINTY 107, 109-10 (J. McCall ed. 1982); Williamson, Credible Commitments: Using Hostages to Support Exchange, 73 AM. EcoN. REv. 519, 522-26 (1983) (developing a formal hostage model in the context of private ordering in intermediate product markets). 
should deter Seller from evasion but not tempt Buyer to cheat. ${ }^{103}$ This result is ensured if the asset's value to Seller is idiosyncratic. On the other hand, where the assets are readily marketable, both parties profit if Buyer is restramed from foreclosing on the bond when the relationship is threatened by adjustment crises. ${ }^{104}$

Self-enforcing agreements are not costless mechamisms. They require substantial monitoring and a punitive sanction for evasive tactics. Even if the noncooperating party understands and "accepts the punishment," retaliation imposes stress on the relationship that may threaten a cooperative equilibrium. It is in the parties' mutual interests to ground the relationship within an established network of social norms. This makes enforcement, when necessary, easier to administer and accept.

\section{b. Norms, Ethics, and Other Informal Mechanisms for Social Control}

Scholars have long recognized that group generated norms, individual ethics, and other informal mechanisms play important roles in regulating contractual relationships. ${ }^{105}$ While we are a long way from an accepted theory of social control, few would quarrel with the assumption that many informal norms and ethical systems serve a functional purpose. ${ }^{106}$ For the purposes of this essay it is only important to see that a number of social forces inay contribute to control of long-term contractual relations.

The pervasive social norm of reciprocity ${ }^{107}$ is particularly relevant

103. See Williamson, supra note 102 , at $526-27$.

104. Scott, supra note 80 , at 930 .

105. See, e.g., I. MACNEIL, THE NEw Soclat Contract: AN INQuiRY into MODERN ContraCtual Relations (1980); Gottlieb, Relationism: Legal Theory for a Relational Society, 50 U. CHI. L. Rev. 567 (1983); Macaulay, Non-Contractual Relations in Business: A Preliminary Study, 28 Am. Sociological Rev. 55 (1963); Macneil, Values in Contract: Internal and External, 78 Nw. U.L. REV. 340 (1983).

106. "The process by which norms develop and are passed on to subsequent generations is unclear, but most social psychologists rely on utilitarian, functionalist premises. See Krebs \& Miller, Altruism and Aggression, in 2 The Handbook of Social Psychology 18-19 (G. Lindzey \& E. Aronson $3 \mathrm{~d}$ ed. 1985). One researcher has argued, for example, that the norm of reciprocity functions as a stabilizing force, cementing social relationships and discouraging exploitation. Gouldner, The Norm of Reciprocity: A Preliminary Statement, 25 AM. Sociological REV. 161, $172-76$ (1960); see also E. WALSTER, G.W. WALSTER \& E. BERSCHERD, EQUITY: THEORY AND RESEARCH 6-8, 15-16 (1978) (socially generated norms of equity serve to prevent individuals from following their natural inclinations to maximize their own outcomes at others' expense).

Robert Ellickson has suggested that absent "social imperfections" (such as the lack of any prospect of a future relationship), "the norms that govern relations among members of a group will tend to maximize the aggregate wealth of group members." Ellickson, A Critigue of Economic and Sociological Theories of Social Control, 16 J. Legal STUD. 67, 98 (1986).

107. Gouldner suggests that there is a universal norm of reciprocity consisting of two fundamental principles: "(1) People should help those who have helped them, and (2) People should not injure those who have helped them." Gouldner, supra note 106, at 171. Substantial evidence from social science research supports the claim that individuals from a variety of cultures behave in accordance with this norm. See, e.g., E. WALSTER, G.W. Walster \& E. BerScherd, supra note 
to contractual interactions. The origins of the cultural disposition to reciprocate remain unclear, but underlying most current theories is the assumption that behaviors that work well in a particular social system are selected, and those that do not are discarded. ${ }^{108}$ The analysis in this Article supports the theory that the norm of reciprocity encourages individuals to behave cooperatively long enough for thein to discover its long-run benefits, thus bridging the gap between short-term and longterm payoffs. ${ }^{109}$

The social norm of reciprocity offers a peculiarly stable foundation for a strategy of conditional cooperation. The strategy seems credible because it relies upon behavioral responses that "go without saying." To be sure, reciprocity standing alone cannot always create a cooperative equilibrium. One need only recall the familiar vaudeville skit of mutual slaps escalating into all out combat to realize that reciprocity can polarize a relationship as well as nurture it. ${ }^{110}$

Other social norms coinpensate for the dangers of "negative" reciprocity. Thus, in many cominercial environments, norms such as honesty, promise keeping, trust, and solidarity are also prevalent. ${ }^{11}$ For example, Stewart Macaulay's study of contractual behavior among business firms found that two norms were almost universally supported: "One ought to produce a good product and stand behind it;" and "Coinmitments are to be honored in almost all situations." 112 These norms reinforce an initial predisposition to cooperate, which is then reinforced by reciprocal interactions. ${ }^{113}$

One explanation for the norms that einerge from business contexts is their utility as supplemental methods of regulation. ${ }^{114}$ Macaulay's study,

106, at 95-98; Gergen, Ellsworth, Maslach \& Seipel, Obligation, Donor Resources, and Reaction to Aid in Three Cultures, 31 J. Personality \& Soc. Psychology 390 (1975); Staub \& Sherk, Need for Approval, Children's Sharing Behavior, and Reciprocity in Sharing, 41 CH1LD DEv. 243 (1970).

108. The relationship between normative standards and normative behavior remains uncertain. Generally, social psychologists assume that normative standards are triggered by paradigmatic situations. Once "activated," these standards then mediate individual normative behavior. See Berkowitz, Social Norms, Feelings and Other Factors Affecting Helping and Altruism, 6 ADVANCES EXPERIMENTAL Soc. PSYchology 63 (1972); Lerner, The Justice Motive: Some Hypotheses as to Its Origins and Forms, 45 J. Personality 1 (1977); Leventhal, The Distribution of Rewards and Resources in Groups and Organizations, 9 AdVANCEs EXPERIMENTAL SOC. PsYchology 91 (1976).

109. Krebs \& Miller, supra note 106, at 28.

110. While it seems intuitively plausible that the norm of reciprocity is retaliatory when one individual is harmed by another, there is some evidence that it serves a more limited and "benign" function. Under this conception, the "eye for an eye and tooth for a tooth" formulation in the Hammurabi Code was intended to restrict revenge by requiring a measured, proportional response. See id. at 25-26.

111. See Ellickson, supra note 106, at 92-93.

112. Macaulay, supra note 5 , at 63 .

113. Ellickson, supra note 106, at 92.

114. See generally Alexander, Evolution and Culture, in Evolutionary Biological and Human Social Behavior, supra, at 59, 68-69 (because culture represents the cumulative maximization of the 
for example, suggests that the ordinary expectation that a seller stands behind a product provides the initial impetus for a precommitment to conditional cooperation. ${ }^{115}$ Thereafter, the obligation to honor commitments deters evasion in instances where the payoffs from short-term exploitation might seem greater than the present discounted value of future interactions. In short, trust, solidarity, and mutual respect may help to solidify the relationship and permit it to survive the myopia of individual decisionmakers. ${ }^{116}$

In addition to group norms, individualized controls on behaviorsystems of personal ethics-are also important regulators. ${ }^{117}$ Durable and frequent interactions among specific individuals can promote cooperation between two firms. While it is unlikely that firms themselves can develop a true interdependence, managers who deal with each other over repeated interactions are a powerful substitute.

\section{Legal Enforcement as a Facilitator of Cooperative Adjustment \\ a. The Benefits of Legal Enforcement}

Because extralegal enforcement mechamisms may not be sufficient to achieve a cooperative equilibrium, it is important to consider the benefits parties may derive from appealing to the state's coercive power to enforce agreements. To understand better the ex ante effects of legal enforcement, assume that all legally binding agreements can be costlessly and perfectly enforced. Under these ideal circumstances, the question is, when, if ever, parties will seek external enforcement of their agreements.

A legal dispute resolution systein has significant advantages over extralegal mechanisms in ameliorating the problems that cause interparty deadlock. These advantages are evident when the parties have a genuine disagreenent over the meaning of key terms in the agreement. As previously discussed, to design a complex strategy for distributing risks, parties must combine individualized express terms with preformu-

interests of "all humans who have lived," it is difficult for particular individuals or groups to "alter it so greatly or rapidly"); Durham, Toward a Coevolutionary Theory of Human Biology and Culture, in Evolutionary Biology and Human Social Behavior: AN ANTHropological Perspective 39, 52 (N.A. Chagon \& W. Irons eds. 1979) (because the well-being of individuals depends on the success of their groups, it is im most individuals' best interest to accept these "norms, rules and cultural controls on selfish individual behaviors").

115. See Macaulay, supra note 5 , at 63 .

116. See Scott, supra note 10 , at 346-47 (arguing that self-generated rules and norms that parties use to manage their choices have a powerful feedback on the process of making judgments).

117. See J.L. MAckie, Inventing Right AND WRoNg 115-20 (1977). The prisoner's dilemma illustrates the

practical value of the notion of obligation, of an invisible and indeed fictitious tie or bond, whether this takes the form of a general requirement to keep whatever agreements one makes or of various specific duties like those of military honour or of loyalty to comrades or to an organization.

Id. at 119. 
lated implied terms. Since the combination of express and implied terms often will be unique, these disputes frequently cannot be resolved by resorting to the parties' collective experience. The state, however, as the developer of inphied terms, enjoys a significant advantage in interpreting the agreenient. This advantage is enhanced by judicial knowledge of the accunulated experience of other, similarly situated contracting parties who have grappled with analogous contingencies. ${ }^{118}$

Furthermore, even if the state had no interpretive advantage, its ability to authoritatively resolve disputes would be a key factor in developing a cooperative equilibriun. One of the effects of the parties' inadequate information is that spiteful interactions inay result when one party inischaracterizes the other's response to an adjustinent choice. Assume, for instance, that one party declines to adjust wlien asked, and instead disputes the meaning of the agreenent. The appropriate response for the party requesting adjustınent depends on whether the dispute is a genume difference of opimion that is consistent with the cooperative pattern, or is an attenipt to evade an assigned risk. Spiteful responses to these uncertainties can quickly generate an "echo" effect of mutual recrimination and retaliation that will threaten the relationship. ${ }^{119}$

Spiteful interactions are at least partially controlled by a legal system that is both authoritative and formally neutral. The state derives authority froin its power to coerce coinpliance with its judgments, and achieves formal neutrahty through its reliance on a set of preexisting rules of adjudication. From the perspective of encouraging a cooperative equilibrium, it is quite irrelevant that the law inay achieve neutrality through a legal process that masks underlying social and economic inequalities.

To be sure, the parties need not rely on judicial resolution of disputes. Frequently they will prefer third-party arbitration to judicial dispute resolution because arbitration often reduces the direct or administrative costs of enforcement. In order to reduce total enforceinent costs, however, the reduction in administrative costs inust be greater than any increase in indirect costs such as the costs of increased error, bias, or nonenforceability. ${ }^{120}$ Arbitration works best, therefore, in

118. To be sure, the state's interpretive advantage is only comparative. The state creates an irreducible risk of "interpretation error" in situations where parties have combined express and implied terms in their agreement. Goetz \& Scott, supra note 85, at 272.

119. A spiteful action is any retaliation generated by a unverifiable belief that the other is taking advantage of contractual uncertainties. See Lef, Injury, Ignorance and Spite-The Dynamics of Coercive Collection, 80 YALE L.J. 1, 18-19 (1970) (cxploring the inefficiency of coercive collection inechanisms as a ineans of dealing with failures of reeiprocity).

120. One of the social costs of arbitration is the lack of published opinions. Dispute resolution is a key method for testing contract terms. Surviving terms are reliable. If those terms that have survived are not generally communicated to the industry, a valuable source of reliable experience is 
specialized environments such as labor law, where the arbitrators develop an acknowledged expertise, operate frequently enough to correct for bias, and issue judgments enforceable by the state.

Finally, and perhaps most importantly, access to legal enforcement provides a credible threat of severe retaliation should one party deviate significantly from the cooperative pattern. Witlout such a "large strike" capability, eacli contracting party would be subject to the other's defection whenever the shadow of the future proved insufficient to prevent evasive behavior. This occurs when the sliort-term gains from defection exceed the present discounted value of future cooperation. Social norms and self-enforcement are unsatisfactory safeguards in this situation. If the parties must stockpile an arsenal of self-enforcing deterrents (sucli as lostages) to guard against substantial defections, they will incur uncompensated costs. Thus, the demand for a mechanism to maintain the fundamental structure of the relationship represents a classic public goods problem. No single set of contractors can hope to capture sufficient benefits from sucli an imvestment to offset the costs of a retaliatory arsenal. As a consequence, there would be no deterrent to large scale defections if the parties were limited to self-enforcing mechanisms.

\section{b. The Limits of Legal Enforcement}

I liave suggested that legal rules can reduce the tensions inherent in the adjustment process that threaten the cooperative equilibrium. Unfortunately, problems arise in the attempt to ensure cooperative adjustment within the constraints of a legally enforceable obligation. These problems are the product of an apparent paradox: Legal enforcement is botl a threat and a temptation. Any enforcement standard that sufficiently deters evasion by one party will inevitably invite evasion by the otlier.

If both parties would benefit by pursuing separate paths, they can mutually agree to termmate their relationship. Problems develop, however, when one party's self-imterest suggests a noncooperative response despite the fact that the parties' joint interest would be better served by maintaining the relationship. ${ }^{121}$ Defection from the cooperative norm

lost. For a discussion of some of the other limitations of conventional arbitration, see infra text accompanying notes 133-36.

121. Given plausible assnmptions about how future preferences are discounted, individuals whose preference-ordering is constant may nonetheless make inconsistent choices over time. Strotz, Myopia and Inconsistency in Dynamic Utility Maximization, 23 REv. ECoN. STUD. 165, 165 (1956); see also Hammond, Changing Tastes and Coherent Dynamic Choice, 43 REv. Econ. STuD. 159 (1976). Contra Pollak, Consistent Planning, 35 REv. ECON. STud. 201, 202 (1968) (concluding that although Strotz's argument for a "strategy of consistent planning" is sound, his calculation of a corresponding consumption plan formula is incorrect). Thus, despite social and legal controls, a contracting party may choose the smaller, more immediate reward from evasion, despite a long term 
may occur in several contexts. Often, a risk will materiahize that threatens the adversely affected party with substantial losses. This may lead the risk bearer to evade its assigned responsibility. For example, sharp and unanticipated price mcreases in the grain and commodities markets in the mid-1970's tempted many farmers to evade their responsibihity for delivering crops at the contract price. They subsequently attempted to escape liability by relying on the statute of frauds as a bar to the enforceability of their oral contracts. ${ }^{122}$ Such behavior is a rational response only when the gams from selling the crop on the open inarket at current prices exceed the value of a continuing relationship with a wholesaler. ${ }^{123}$

Defection may also occur when a party attempts to extract a premium in return for its cooperation im reducing the other's losses. For example, assume that an unanticipated event such as a labor strike mcreases the costs of the goods Seller is bound to deliver under the contract. A legally binding contractual obligation deters evasion by requiring Seller to bear the cost of the price mcrease. But what if Buyer can adjust its dehvery schedule and substantially reduce Seller's loss? Iromcally, the very potential of enforcement simultaneously tempts Buyer to withhold the adjustments that imght minimize Seller's loss. Despite extralegal factors, which encourage cooperation, Buyer may engage in foot dragging, inflating estimates of adjustment costs, or demanding a payoff to cooperate. ${ }^{124}$ This forin of "extortion" may threaten a relationship just as severely as Seller's attempt to evade the assigned risk.

In sum, when an adjustment opportumity arises, the prospect of legal enforcement provides each party with a reciprocal set of options. ${ }^{125}$ As obhigors, they can choose to comply voluntarily with their assigned responsibilities or evade them. Conversely, as obhigees, each party may select an enforcement strategy that is either flexible or severe. If an obli-

preference for the larger, but deferred benefits of cooperation. Cf. Strotz, supra, at 173-75 (discussing similar individual decisions in daily life).

122. See, e.g., Loeb \& Co. v. Schreiner, 294 Ala. 722, 321 So. 2d 199 (1975); Decatur Coop. Ass'n v. Urban, 219 Kan. 171, 547 P.2d 323 (1976); Nelson v. Union Equity Coop. Exch., 548 S.W.2d 352 (Tex. 1977). See generally A. ScHWARTZ \& R. ScoTT, supra note 1, at 40-42 (analyzing the problem of characterizing farmers as merchants under U.C.C. $\$ 2-202(2))$.

123. The cotton farmer problem is inore complex than this example suggests. The farmers can evade once and then explicitly agree not to repeat this behavior. Similarly, a manufacturer can make defective products and thereafter offer elaborate warranties to offset the fallout from the first episode. This analysis merely suggests, however, that reputational restraints are insufficient, standing alone, to generate a cooperative equilibrium. See Klein \& Leffler, supra note 75, at 623.

124. See, e.g., Alaska Packers Ass'n v. Domenico, 117 F. 99 (9th Cir. 1902); Lingenfelder v. Brewing Co., 103 Mo. 578, 15 S.W. 844 (1891); Austin Instrument, Inc. v. Loral Corp., 29 N.Y.2d 124, 272 N.E.2d 533 (1971). See generally Muris, Opportunistic Behavior and the Law of Contracts, 65 MiNN. L. REV. 521 (1981).

125. The following discussion of the dilemma of devising optimal enforcement systems draws on Scholz, Cooperation, Deterrence, and the Ecology of Regulatory Enforcement, 18 LAW \& Soc'Y REv. 179 (1984). A similar model had occurred to me independently and is sketched out in Goetz \& Scott, supra note 24 , at $983-84$. 
gee adopts a flexible strategy-such as permitting deviations within an acceptable range and voluntarily undertaking any appropriate adjustments-and the obhgor complies fully with its responsibilities, then both parties benefit from mutual cooperation. Both sides thus avoid expensive enforcement costs.

On the other hand, if the obligor evades responsibility and the obligee resorts to coercive legal enforcement, both incur substantial costs in the resulting hitigation. Moreover, each obhgor is tempted to evade its responsibihities if the obhigee announces a flexible enforcement policy that makes legal sanctions improbable. Conversely, an obligee is tempted to use the threat of tough legal sanctions to extract a premium for cooperation.

The severity of the enforcement standard contributes a new dimension to the parties' decisionmaking. ${ }^{126}$ A flexible performance standard, such as the doctrine of substantial performance which governs construction contracts, reduces both the clarity of the standard and the severity of legal enforcement, thereby increasing evasion by obligors. ${ }^{127}$ The desire to restrain evasion may instead motivate the parties to adopt clear but tough standards, such as the perfect tender rule. Although these brightline rules do deter the obligor from evasion, they also tempt the obligee to defect by demanding a premium in exchange for relaxing the tough enforceinent rule. In short, tough enforcement standards are potentially incompatible with the desire for flexible and adaptive adjustments.

The tension between the tough standards needed for effective enforcement of the imitial distribution of risks and the flexible enforcement necessary to encourage cooperative adjustment is inherent in the legal regulation of long-term contracts. Thus, while legal enforceinent can be beneficial in encouraging cooperative adjustment, it is not a panacea. Admitting and understanding the limits of legal enforcement in reahistic contractual relations reveals the myopia of conteinporary legal discourse. We must examine contractual relationships within a broader matrix of social control that encompasses both legal and extralegal forces.

\section{Patterned Cooperation in a Bargaining Regime}

Legal and extralegal regulatory systems reduce, but do not eliminate, the problems caused by imperfect information and enforcement. In order to analyze the effects of these chronic deficits, I now relax my earher assumption that the parties are unable to bargain about adjustment

126. See Scholz, supra note 125 , at 182 .

127. The flexibility of the substantial performance standard removes opportunities to exploit inadvertent breaches. Such a rule is sensible in construction contracts, where renegotiation costs otherwise would be substantial. See Goetz \& Scott, supra note 24, at 1010 \& n.116. 
opportunities. Assunie, to the contrary, that parties to long-term contracts may formally renegotiate contracts at positive but not prohibitive costs. In this nore realistic contractual setting, patterns of cooperation are still valuable. Patterned behavior now beconies a powerful econonizer, reducing the costs of conflicts that otherwise impair the relationship.

\section{The Economizing Function of Cooperation}

The capacity of contracting parties to bargain about adjustnients does not mean that renegotiation will be a common response to an adjustment problent. Whether parties resolve an adjustment crisis by formal renegotiation or cooperative adjustnient depends on the relative costs and benefits of each alternative. Because patterned cooperation is reflexive and habitual, it is less costly than a renegotiated adjustment. ${ }^{128}$ Whenever adjustment problenis are bargained, a party with specialized skills becoines more vulnerable to strategic responses from the other. The threat of excessive renegotiation costs therefore induces each party to invest in alternative arrangements as precautions against a bargaining iinpasse.

Cooperative adjustinent reinains a powerful regulator of long-term contractual relationships despite the fact that major adjustinent crises may require individualized responses. ${ }^{129}$ The higher stakes in these cases will justify the additional costs of renegotiation. Recognizing that contracting parties must accommodate the risks of both large-scale and conventional defections illuminates how nonlegal factors that reinforce patterned behavior relate to legal enforcenient.

Stewart Macaulay has established that the recurring, conventional problenis of niaintaining cooperative relationships in a business setting are chiefly enforced through nonlegal niechanisms. ${ }^{130}$ The common business attitude is reflected in one subject who reports: "[I]f something

128. The advantages of cooperative adjustment include savings in insurance costs, negotiating time, and lawyers' fees. A precommitment to conditional cooperation also eliminates the costly strategic behavior that attends renegotiation.

129. Adhering to a preestablished rule of behavior for managing these complex choices removes the responsibility for the particular choice from the decisionmaker and thereby reduces regret and decisionmaking costs. The phenomenon of "regret aversion" assumes that the status quo is the reference point individuals use to evaluate future choices in terms of relative gains and losses. Making choices carries a decisionmaking cost, because taking responsibility has secondary consequences. Individuals feel regret if a loss occurs as a result of their decision and pride if their choice results in gain. But individuals weight the anticipated cost of regret more heavily than the corresponding benefit of pride. All other things being equal, individuals are thus reluctant to make choices where they feel responsible for the outcomes. See Scott, supra note 10, at 337-42; Thaler, Toward a Positive Theory of Consumer Choice, 1 J. ECON. BEHAV. \& Organization 39, 52-54 (1980).

130. Macaulay, supra note 105 , at 61 . 
comes up, you get the other man on the telephone and deal with the problem. You don't read legalistic contract clauses at each other if you ever want to do busmess agam."131 As an example of how well established this attitude is, Macaulay tells of the large manufacturer of packaging materials who mspected its records and found that it had failed to create legally binding contracts in two-thirds of the orders randomly selected for review. ${ }^{132}$ The mere anticipation of mutually rewarding future transactions mamtains the cooperative equilibrium in such cases.

Macaulay concludes that commercial relationships are largely governed by "social" as distmct from "legal" norms. But this conclusion is incomplete. It is precisely when this anticipation of future interactions breaks down (im cases where the sliort-term payoffs froin defection are substantial) that parties are likely to request renegotiation and raise its attendant threat of legal enforcement. Thus, individualized and patterned responses regulate different aspects of the contractual relationship in mucli the same way as conventional and nuclear weapons deter against different acts of aggression and noncooperation by the superpowers.

\section{Reducing the Adjustment Variance by Contract}

Tradeoffs between cooperative adjustment and renegotiation also affect the ex ante bargaining process. The major threat to a cooperative equilibrium is the variance in the inagiritude of adjustment crises. The degree of adjustinent required in any circumstance correlates to each party's teinptation to evade its contractual responsibility. Social norms and self-enforcing agreeinents help to regularize this variance by reducing the divergence between short-term exploitation and long-term cooperation.

Contracting parties may also modify the initial risk distribution sclieme because they anticipate a large-scale adjustment crisis and its attendant costs in terms of renegotiation or breakdown. One possibility is to craft the initial risk assignment so as to reduce the expected variance of any future adjustment. For exannple, Victor Goldberg argues that a complex price adjustment mechanisin, such as the one developed in Alcoa, ${ }^{133}$ functions principally to reduce the bargaining range for future renegotiation ratler than to allocate risks efficiently. ${ }^{134} \mathrm{By}$ adopting a risk-sharing strategy at the outset, parties can reduce the stress on subsequently developed patterns of cooperation. Unfortunately, this risk-sharing strategy may also sacrifice some of the potential for risk reduction

131. Id.

132. Id. at 60.

133. Aluminum Co. of Am. v. Essex Group, Inc., 499 F. Supp. 53 (W.D. Pa. 1980); see supra text accompanying notes 13-14.

134. Goldberg, supra note 16, at 531-33. 
that a binary allocation would provide. The parties may therefore tolerate a short-term failure to assign risks ideally in order to preserve their long-term objectives.

Contracting for dispute resolution mechanisms other than mediation, arbitration, or litigation may provide an additional means of reducing the risk of high variance adjustment. While mediation and arbitration may be less costly than traditional hitigation, sucli conventional techniques are not hikely to effectively enforce cooperation im many long-term contracts. Mediation is essentially an extended settlement negotiation where parties exchange confidential information to neutralize the risk of mischaracterization of the other's actions. Arbitration is a similarly attenuated adversarial process for autloritatively resolving disputes. Conventional dispute resolution methods thus encourage the parties to tolerate disputes during the performance of the contract, and to seek resolution only after the relationship has terminated. ${ }^{135}$ In contrast, the cooperative model argues for immediate and authoritative resolution of disputes while the teinpering influence of the continuing relationship can be used to discipline evasion.

A more sensible means of exploiting the considerable power of the long-term relationship may be appointment of a permanent contract referee. ${ }^{136}$ The referee is essentially a single arbiter who can minimize both information and enforcement probleins on an ongoing basis. Indeed, a skillful referee can serve both conventional arbitration and mediation goals. Ideally, the contract referee would be autlorized to investigate, inspect or discover facts; to require the parties to adjust cooperatively; and to issue a final and binding judgment where the disagreement cannot be resolved. Such a mechanism has the distinct advantage of complementing rather than undermining the social controls that promote patterns of conditional cooperation.

To recapitulate: Contracting parties use a mix of legal and extralegal inechanisms, as well as patterned and individualized responses, to ameliorate the information and enforcement deficits that threaten emergent patterns of cooperation. Nevertheless, contractual breakdowns are inevitable. Patterns of cooperation in contractual relationships are inherently unstable, especially where one party is threatened with substantial losses (or tempted by substantial gains). Where the necessary adjustments are of lesser inagnitude, however, social norms aimed at inducing long-term cooperation will often proinpt adjustment, and legal rules provide appropriately remote, but harsh, deterrents and incentives.

135. J. Myers, Why Conventional Arbitration is Not Effective in Complex Long-Term Contracts 12-15 (paper presented at International Symposium on The Complex Long-Term Contract, Heidelberg, Germany, Oct. 2-3, 1986).

136. Id. at $22-25$. 


\section{Normative Implications}

\section{The Role of Binary Legal Standards in a Regime of Flexible Enforcement}

The symbiotic relationship between legal rules and social control mechanisms may explain why contract law fraines its customary risk assignments in terms of categorical, binary rules, such as the doctrines of perfect tender, mistake, excuse due to superveming cause, and breach of contract. ${ }^{137}$ These rules assign risks on an all-or-nothing basis, thereby deterring evasion better than multifactored formulations, but tempting obhigees to extort a premium in exchange for their agreement to enforce the rules flexibly. ${ }^{138}$ Indeed, this tension best explains the anomaly of well-developed legal doctrines of commercial impracticability and frustration and the courts' simultaneous reluctance to excuse nonperformance in particular cases. ${ }^{139}$ Legal rules facilitating a cooperative equilibrium must strike a balance between tough and flexible enforcement of contractual obligations. Where the legal doctrines are formulated in bimary terms-perform in full or excuse entirely-this balance may require combining a flexible general rule with a tough enforcement pohicy for particular cases. ${ }^{140}$

The cooperative model resolves the apparent paradox of legal enforcement. Under this conception, the many binary contract rules serve as effective complements to the more flexible extralegal mechanisms that regulate adjustment. More complex, multifactored rules may thus be undesirable to most contracting parties because they sacrifice clarity in return for only marginally reinforcing existing patterns of cooperation.

In cases such as Alcoa or Westinghouse, ${ }^{141}$ however, where one

137. Breach of contract has a binary character which $I$ have described elsewhere as the "breacher-status" problem. There is only one breacher, and he frequently loses the entire benefit of his bargain. See Goetz \& Scott, supra note 24, at 983-84.

138. See supra text accompanying notes 126-27.

139. See supra note 1 .

140. The incongruity between the existencc of legal doctrines authorizing excuse and the reluctance of courts to find the conditions for excusing performance satisfied is a function of the complexity of sorting out the parties' ex ante risk assignments. A court must approach excuse cases with either a strong presumption in favor of enforcement of the contract or a willingness to adjudicate the issues on a case-by-case basis. Under these circumstances, the enforcement presumption generates stronger incentives for the parties to create force majeure and other exculpatory clauses tailored to their own needs.

141. Florida Power \& Light Co. v. Westinghouse Elec. Corp., 517 F. Supp. 440 (E.D. Va. 1981); In re Westinghouse Elec. Corp. Uranium Contracts, 436 F. Supp. 990 (J.P.M.D.L. 1977) (transferring all related actions to the federal district court for consolidated pretrial proceedings). The Westinghouse Corporation had made long-term contracts to supply large amounts of uranium at fixed prices to power companies that used nuclear reactors. A price rise in uranium concentrate would have subjected Westinghouse to a loss of approximately two billion dollars if all its contracts were enforced. Westinghouse refused to perform and subsequently negotiated settlements with somc 
party's gross misfortune is matched by the other's huge windfall, the long-run benefits of cooperation pale against the enormous short-term gains from evasion. The relevant contract rules do not prevent breakdowns in such "high variance" cases because their all-or-nothing character is much more of a disadvantage when so much more is at stake. Even so, unpredictability as to the interplay between legal and extralegal methods of maintaining a cooperative equilibrium argues for restraint in judicially imposing adjustments. Given the highly interactive nature of the parties' responses, it is difficult to know whether one party's refusal to adjust cooperatively in a particular case represents exploitative behavior or a measured, retaliatory response to an earher noncooperative action by the other. Because of this uncertainty, any legally-imposed adjustment inay create perverse incentives that undermine the stability of the cooperative equilibrium of contracting parties.

Specialized contractual relationships may require more varied and coinplex mechanisms than the current set of legal rules provide if contracting parties are to achieve an optimal resolution of their conflicting goals. The cooperative model developed in this Article, however, suggests that contracting parties may nonetheless prefer the categorical, binary rules of contract law when the social norms break down. This analysis at least partially explains the puzzling divergence between the frequently observed patterns of cooperative adjustment and many of the infiexible rules of contractual obligation. Visualizing legal rules as part of an interrelated system of contractual cooperation reconciles some of these apparent paradoxes.

\section{Improvements in Legal Signaling and Enforcement}

The preceding argument does not miply that efforts to create more innovative legal mechanisins are either futile or counterproductive. As explained earlier, a systennatic bias underhes the process that generates legally standardized signals for the various risk-bearing strategies parties use. ${ }^{142}$ Many of the information problems discussed result from the misinterpretation of siguals. These interpretation errors stem from the power of custoinary implied terms to dominate efforts to create a unique alternative. ${ }^{143}$ This, in turn, suggests that the number and variety of express invocations is inadequate. The probleins arising under the stan-

of its major suppliers. Others brought suit for breach of contract. For a discussion of the factual and legal background, see Joskow, Commercial Impossibility, The Uranium Market and the Westinghouse Case, 6 J. LEGAL STUD. 119 (1977). For a similar case involving Atlas Corporation's uranium contracts, see Iowa Elec. Light \& Power Co. v. Atlas Corp., 467 F. Supp. 129 (N.D. Iowa 1978), rev'd on other grounds, 603 F.2d 1301 (8th Cir. 1979), cert. denied, 445 U.S. 911 (1980).

142. See supra notes $97-101$ and accompanying text.

143. See supra text accompanying notes 91-94. 
dard force majeure and gross mequities (or good faith adjustment) clauses vividly demonstrate this inadequacy.

In the case of force majeure provisions, for example, the standard clause deals adequately with the routine situations such as a short strike, or Acts of God such as fire or flood. ${ }^{144}$ However, many adjustment contingencies involve "economic" force majeure, such as an oil embargo, the enactment of new government regulations, or an unstable labor force. These events generate risk-bearing uncertamties that the standard formulations cannot resolve. For instance, when does a supplier become aware of the occurrence of these economic contingencies? Is excessive absenteeisin the type of labor problein that is embraced in the words "industrial disturbances"? Do the words "and any other case, whether of the kind enumerated or otherwise"145 apply only to "unforeseen" events? After all, it is entirely "foreseeable" that these kinds of events will occur, rendering perforinance mipracticable. Indeed, that is the very reason for including a force majeure clause in a contract. Yet absent a legally recognized invocation that expressly trumps the foreseeability notion, the parties must either enumerate each contingency in detail or face the uncertamty that a court will mterpret the general language in a force majeure clause as excusing only unforeseeable contingencies. ${ }^{146}$

Similar problems plague the application of adjustment provisions such as the typical gross inequities clause. ${ }^{147}$ What constitutes a gross inequity or "an unusual economic condition"? What is meant by adjustment through mutual consent? Suppose one party refuses to cooperate? It remains entirely unclear whether, and to what extent, a standard gross inequities claim is legally enforceable. ${ }^{148}$

In sum, the current process of judicial interpretation and occasional legislative codification has produced insufficient conventions for formu-

144. See supra note 34 .

145. Young, supra note 34 , at 156-57.

146. See, e.g., Eastern Airlines, Inc. v. McDonnell Douglas Corp., 532 F.2d 957, 989-92 (5th Cir. 1976) (General language in force majeure clause excuses only unforeseen events that prevent performance.). This unforeseeability requirement was criticized in Opera Co. v. Wolf Trap Found., 817 F.2d 1094, 1102 n.14 (4th Cir. 1987).

147. The following is a typical gross inequities clause found in a long-term coal supply agreement:

Any gross inequity that may result in unusual economic conditions not contemplated by the partics at the time of the execution of this agreement may be corrected by mutual consent. Each party shall in the case of a claim of gross inequity furnish the other with whatever documentary evidence may be neeessary to assist in effecting a settlement. Nothing contained in this section shall be construed as relieving either the purchaser or seller from any of its respective obligations hereunder solely because of the existence of a claim of inequity or the failure of the parties to reach an agreement with respect thereto. Young, supra note 34, at 143.

148. Georgia Power Co. v. Cimarron Coal Corp., 526 F.2d 101 (6th Cir. 1975), cert. denied, 425 U.S. 952 (1976) is a rare reported case considering the enforceability of a gross inequities claim. The court merely held that the claim was arbitrable. 
lating individualized risk-bearing arrangements. Contracting parties often must resort to uncertain signals. For parties to long-term contracts, therefore, interpretive disputes-with their attendant stress on the cooperative norm-are inevitable until the state provides the requisite instruments for more accurate signaling.

\section{CONCLUSION}

The bargain theory of contract has dominated legal scholarship for well over one hundred years. In its most recent inamifestation-the hypothetical bargain heuristic-the theory continues to eurich our understanding of the source and function of many legal rules. Over the past decade, however, scholars from diverse academic traditions have begnn to focus attention on relational contexts in which some of the assumptions of bargain theory inay no longer hold. Despite the advances in relational theory, ${ }^{149}$ a subtle and lingering effect of the preoccupation with the bargain paradigm has been an imphicit assumption that ex ante and ex post bargains are the only mechanisms by which contractimg parties achieve their objectives. Modern decision analysis and gaine theory offer an alternative heuristic, one that illuminates the regnlatory power of nonbargained patterns of reciprocal cooperation.

By miagining contracting parties as unable to bargam over adjustment, we can analyze their relationship im terms of a strategic interaction game, such as a prisoner's dilemina. This exercise reveals the power of patterns of behavior based upon a principle of reciprocation. Although parties to long-tern contracts are removed from the discipline of a competitive inarket, patterned adjustments that are both predictable and contingent will tend to develop and stabilize the relationship. In real-world interactions where parties can bargain over adjustments, these patterns continue to function as powerful economizers by reducing the costs of bargaming.

The failure of bargain theory to explain contractual behavior completely does not justify the contrary inference that bargaiming is an insignificant force in long-ternn contracting. Rather, the relational context is a complex environment of many regulatory systems, includimg individualized and patterned responses, legal and social norins, and ex ante and ex post bargains. The challenge for contract law is to construct a legal apparatus that complements these forces. As a first step, we must abandon the assumption of legal centrism and acknowledge our mcomplete understanding of contractual relationships and of the linkages between

149. The tentative state of the scholarly project is exemplified by the different labels given to analyses of conflicts of interest. Thus, what I describe as relational theory travels as well under the name "agency theory" or "transactions costs theory." No wonder we have a hard time penetrating traditional analyses. 
legal rules and social norms. Although a game theoretic framework does not offer specific prescriptive guidance, it does offer a cautionary perspective for those who advocate judicially imposed adjustment of long-term relationships.

To be sure, reciprocal cooperation does not ensure equilibrium in long-term contractual relationships. Inescapable information and enforcement deficits will frequently threaten to generate a counterpattern of mutual conflict. Understandably, manifestations of conflict, such as those in Alcoa, invite more elaborate regulation of these relationships. However, legal intervention to forestall noncooperation may have offsettimg effects on the social norms within which the relationship has evolved. I conclude, therefore, that the law's traditional deference to party autonomy may well reflect the most sensible accominodation of the conflicting goals of long-term contractual relationships. 


\section{California Law Review}

\begin{tabular}{lll}
\hline \hline Vol. 75 & DeCEMBER 1987 & No. 6 \\
\hline \hline
\end{tabular}

Copyright (C) 1987 by California Law Review, Inc.

\section{BOARD OF EDITORS}

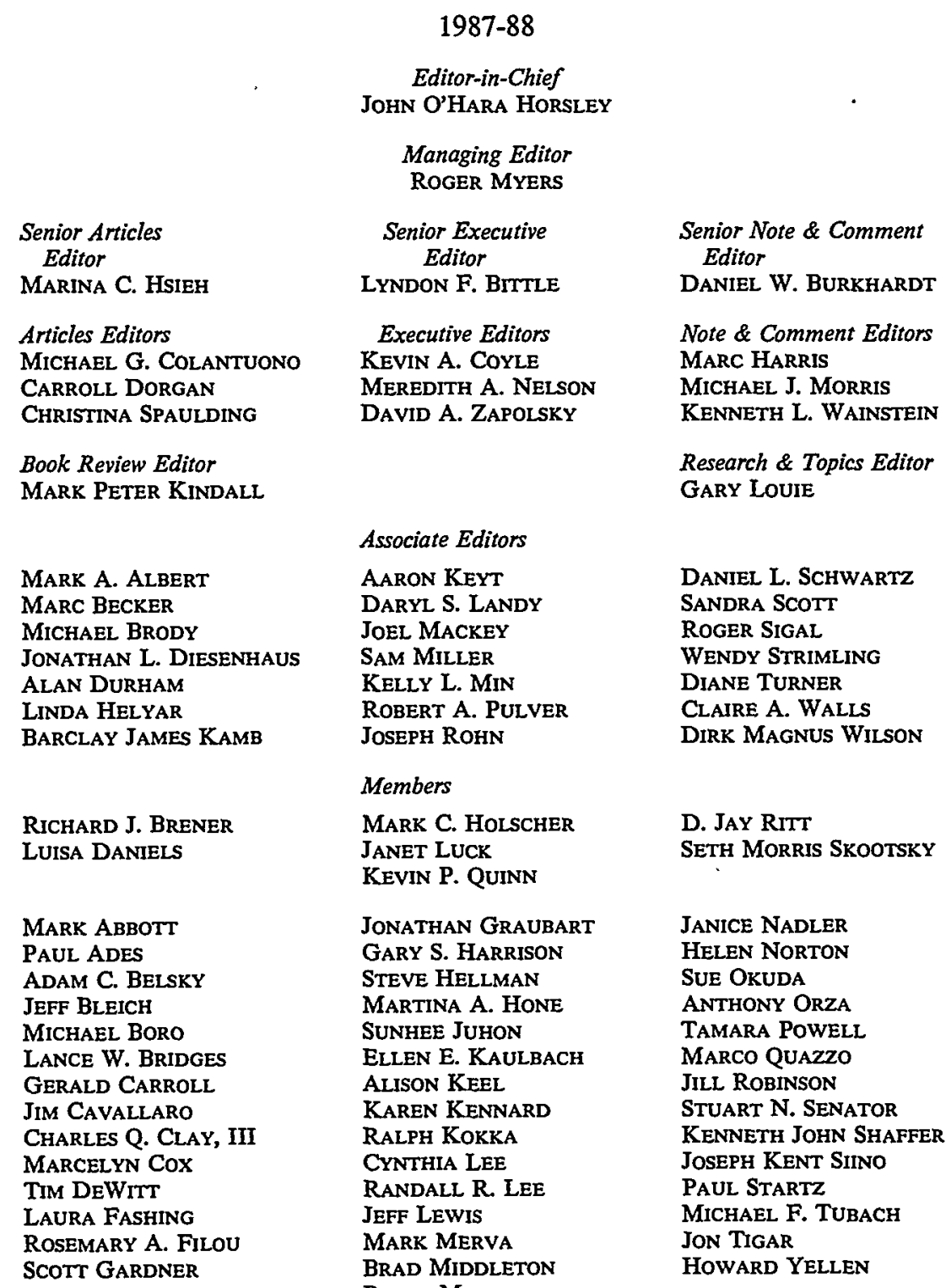


